\title{
Application of a Barrier Filter at a High Purity Synthetic Graphite Plant CRADA 99-F035, Final Report
}

\author{
August 2000
}

\author{
U.S. Department of Energy \\ National Energy Technology Laboratory \\ P.O. Box 880, 3610 Collins Ferry Road \\ Morgantown, WV 26507-0880 \\ and \\ Superior Graphite Company \\ 10 Riverside Plaza, Suite 1600 \\ Chicago, IL 60606
}




\section{Disclaimer}

This report was prepared as an account of work sponsored by an agency of the United States Government. Neither the United States Government nor any agency thereof, nor any of their employees, makes any warranty, express or implied, or assumes any legal liability or responsibility for the accuracy, completeness, or usefulness of any information, apparatus, product, or process disclosed, or represents that its use would not infringe privately owned rights. Reference therein to any specific commercial product, process, or service by trade name, trademark, manufacturer, or otherwise does not necessarily constitute or imply its endorsement, recommendation, or favoring by the United States Government or any agency thereof. The views and opinions of authors expressed therein do not necessarily state or reflect those of the United States Government or any agency thereof. 


\section{TABLE OF CONTENTS}

\section{Section}

1.0 INTRODUCTION

Title

Page

2.0 APPROACH

3.0 BARRIER FILTER APPLICATIONS

3.1 Types of Barrier Filters

3.2 Fundamental and Design Issues

3.2.1 Pressure Drop Considerations

3.2.2 Barrier Filter Design Considerations

3.3 Barrier Filter Markets

3.4 Experience in Similar Service as Superior Graphite

4.0 SUPERIOR GRAPHITE'S BARRIER FILTER SYSTEM DESIGN

4.1 Kickoff Meeting

4.2 Hopkinsville Plant Process Description

4.3 Technical Issues

4.4 Barrier Filtration System Process Design

4.5 Filter Evaluation

4.5.1 Particulate Filter Functional Specification

4.5.2 Particulate Filter Selection

4.6 Other Systems and Equipment

4.6.1 ID Fan Functional Specification

4.6.2 Damper and Ducting Arrangement

4.6.3 Nitrogen Inerting System

4.7 Conceptual Designs

4.7.1 Vendor 1 Design

4.7.2 Vendor 3 Design

5.0 COST ESTIMATE

6.0 CONCLUSIONS

7.0 REFERENCES
8

9 


\section{LIST OF TABLES}

No.

Title

$\underline{\text { Page }}$

3-1 Overview of Particulate Control Device Developers

6

3-2 Barrier Filter Applications Cited by Vendors 11

4-1 After Burner Gas Composition at Design Conditions 15

4-2 Diluted and Cooled Gas Composition at Design Conditions 16

4-3 Filter Data Summary $\quad 22$

4-4 Fan Functional Specification $\quad 24$

5-1 Detailed Estimate for Vendor 1 Design 35

5-2 Equipment List for Vendor 1 Design 37

5-3 Detailed Estimate for Vendor 3 Design 38

5-4 Equipment List for Vendor 3 Design 40

\section{LIST OF FIGURES}

No. Title

Page

3-1 Differential Pressure Versus Time 9

4-1 Plant Flow Diagram 16

4-2 Barrier Filter System Block Flow Diagram 20

4-3 Vendor 1 Design - Plot Plan 26

4-4 Vendor 1 Design - Filter Vessel Isometric $\quad 27$

4-5 Vendor 3 Design - Plot Plan 30

4-6 Vendor 3 Design - Filter Vessel Isometric 31 


\subsection{INTRODUCTION}

Superior Graphite Company and the U.S. Department of Energy have entered into a Cooperative Research and Development Agreement (CRADA) to study the application of ceramic barrier filters at its Hopkinsville, Kentucky graphite plant. Superior Graphite Company is a worldwide leader in the application of advanced thermal processing technology to produce high purity graphite and carbons. The objective of the CRADA is to determine the technical and economic feasibility of incorporating the use of high-temperature filters to improve the performance of the offgas treatment system. A conceptual design was developed incorporating the ceramic filters into the offgas treatment system to be used for the development of a capital cost estimate and economic feasibility assessment of this technology for improving particulate removal. This CRADA is a joint effort of Superior Graphite Company, Parsons Infrastructure and Technology Group, and the National Energy Technology Laboratory (NETL) of the U.S. Department of Energy (DOE).

The Superior Graphite plant, located in Hopkinsville, Kentucky, produces high purity synthetic graphite by removing sulfur and other constituents from calcined petroleum coke in hightemperature electric induction furnaces. Operating at temperatures exceeding $2760^{\circ} \mathrm{C}\left(5000^{\circ} \mathrm{F}\right)$, this process converts amorphous carbon to graphite and generates a flue gas containing $\mathrm{N}_{2}, \mathrm{CO}$, $\mathrm{H}_{2} \mathrm{~S}$, and other sulfur compounds, along with particulate matter emissions. Gases exit the furnaces at temperatures on the order of $1980^{\circ} \mathrm{C}\left(3600^{\circ} \mathrm{F}\right)$. The Hopkinsville plant has multiple furnaces, each with an afterburner. The gases are cooled in a gas cooler by dilution air to 250 to $325^{\circ} \mathrm{C}\left(480\right.$ to $\left.620^{\circ} \mathrm{F}\right)$. Then the gases are manifolded to a single multiclone dust collector and subsequently sent to a dual alkali sulfur dioxide scrubber system. In addition to the $\mathrm{SO}_{2}$ absorption tower, the scrubber contains multiple mist eliminators and multiple rotary atomizers, which are also equipped with downstream mist eliminators. The latter are for fine particulate control and mist suppression geared toward minimizing stack opacity. Efforts are underway to improve both particulate emissions and opacity, which is the focus of this evaluation.

The particulate matter coming from the furnaces consists of coke dust and ash. The use of a hightemperature filter downstream of the afterburner but upstream of the scrubber to remove coke dust and ash could provide several benefits including:

- Removal of the particulates going to the scrubber.

- Reduction of particulates entrained in the scrubber tower and dissolved solids in the scrubber mist.

To better define the technical issues and the costs versus benefits of this option, conceptual designs and cost estimates of the use of a barrier filter in this application were performed. 


\subsection{APPROACH}

The following tasks were completed during the course of this agreement:

- Confidentiality Agreement - A confidentiality agreement was developed and executed between Superior Graphite and Parsons Infrastructure and Technology Group.

- Plant Information Sheets - Parsons developed and submitted to Superior Graphite a request for information sheet. The information request sheet queried Superior Graphite on the plant operating and design parameters. General areas of interest included local environmental conditions, process operating range (temperature, pressure, and flow rates), expected filter design conditions, flue gas composition, and particulate morphology. Information not available was estimated in consultation with Superior Graphite.

- Site Visit - A site visit was conducted to tour the Superior Graphite facility located in Hopkinsville, Kentucky. At that time discussions were held to identify technical issues that must be addressed, to finalize the conceptual design basis, and to agree upon the costing scope.

- Site-Specific Conceptual Design - Parsons developed site-specific conceptual designs for the Hopkinsville, Kentucky plant. The conceptual designs were generated to illustrate how a barrier filter system could be integrated into this Superior Graphite plant. The designs conceptually addressed technical issues identified at the site visit. The conceptual designs included a system diagram, system and component descriptions, and a general arrangement drawing. Vendor input was solicited for major equipment.

- Cost Estimate - Parsons produced a capital cost estimate based on the system scope as described in the conceptual design. The estimate was based on equipment quotes and inhouse cost data. Parsons also identified the operating and maintenance $(O \& M)$ requirements.

- Engineering Report - An engineering report was developed by Parsons to present the conceptual design, capital cost estimate, and an assessment and description of the technical issues as they apply to the Hopkinsville plant. 


\subsection{BARRIER FILTER APPLICATIONS}

Development of hot gas cleanup technologies has tended toward producing a barrier type filter, capable of meeting the ever-decreasing limits for particulate emissions, that is free from the restriction of temperature excursion vulnerability. Conventional technologies are limited to operating temperatures lower than 260 to $315^{\circ} \mathrm{C}\left(500\right.$ to $\left.600^{\circ} \mathrm{F}\right)$. Filtration at higher temperatures can offer several advantages including:

- Elimination of the need for gas cooling or gas dilution equipment.

- Reduction of maintenance by avoiding dew point corrosion problems.

- Increasing efficiency by recovering additional energy or valuable byproducts.

Twenty years ago hot gas barrier filters were almost unknown, with the exception of a few specialized applications. Barrier filters are now commercially available for moderate temperature and pressure (less than $1000^{\circ} \mathrm{F}$ and $1 \mathrm{~atm}$ ) applications with the availability of several products in the U.S. and Europe market and the practical application in numerous industrial sectors. ${ }^{1}$ The market barriers of cost and reliability have prevented widespread applications of these filters. However, these barriers should begin to fade as the filters are more widely accepted in the marketplace due to more stringent emission regulations being placed on the user.

The DOE's involvement with high-temperature, high-pressure particulate removal started in 1978, primarily for pressurized fluidized bed combustion (PFBC) and integrated gasification combined cycle (IGCC) applications. These were at higher temperature $\left(1200\right.$ to $\left.1500^{\circ} \mathrm{F}\right)$ and pressure $(10$ to $25 \mathrm{~atm}$ ) than most industrial applications. At least 10 devices were tested at a bench scale under simulated PFBC conditions. In 1982 two devices, a ceramic felt bag filter and an electrostatic precipitator (ESP), were installed at the Curtiss-Wright PFBC pilot plant and tested at actual PFBC conditions. In 1986 a granular bed filter, a redesigned ESP, and a ceramic crossflow filter were tested at the New York University PFBC pilot plant.

In Europe, silicon carbide candles were being tested in England at Grimethorpe's PFBC and at other test facilities in Germany and Finland. By 1989, the candle filter appeared to have the best chance for success in both PFBC and IGCC environments. A demonstration-scale test of a candle filter was done at the Tidd PFBC plant. Results of the final series of tests were positive, although long-term testing above $815^{\circ} \mathrm{C}\left(1500^{\circ} \mathrm{F}\right)$ was still needed. Other devices such as cross-flow filters, ceramic tube filters, and granular bed filters continue to be developed, but will need much more testing at pilot and demonstration plant scale before acceptance is attained.

Presently, the DOE is sponsoring a coordinated program to commercialize hot gas particulate collection technology. This program includes research and development, slipstream testing, and pilot plant testing at the Power Systems Development Facility (PSDF) in Wilsonville, Alabama, and clean coal technology demonstration plants. ${ }^{2}$ 


\subsection{TYPES OF BARRIER FILTERS}

The most common form of barrier filters is referred to as a "candle," closed at one end and open at the other. ${ }^{3}$ Candle filters are typically suspended from a tube sheet, which may be made from high-temperature metal, or from ceramic in the case of the lighter weight ceramic filters. Each tubesheet holds an array of individual candles, and tubesheets may be grouped horizontally and vertically. Tubesheets may be solid, or hollow for water-cooling. The filters are closed or sealed on one end and flanged on the other end for mounting on the tube sheet. Dirty gas impinges on the outer surface of the candle and clean gas is carried away down the hollow center of the candle. The particulates are captured on the outer face of the candle and cleaned off with pulses of compressed air directed down the center of the candle, much as in a reverse pulse jet filter. Captured particulates then fall down from the filters and are collected in a hopper.

The main difference between ceramic media and conventional fabrics results from the ceramic nature of the material. This gives the filter the capability of operating at sustained high temperatures and in corrosive atmospheres. The media are unaffected by sparks and can even withstand combustion of the collected solids on the surface of the filter elements for short periods of time. Acid or alkali materials have little or no effect on the materials. ${ }^{4}$

As with fabric filters, the bulk of the filtration is achieved by the buildup of a porous cake of particulates on the surface of the filter, which prevents further penetration of the media. In some situations, this barrier of dust is artificially added (pre-conditioning) to improve the filter's performance. This barrier, or conditioned, layer of particulate matter gives an increase in pressure drop over the original media. However, it also gives rise to excellent filtration efficiencies. Because this conditioned layer is permanent, the rigid ceramic elements do not clean down completely when pulse cleaned as fabric filters do. This results in virtually no penetration of the filter and can result in less than $5 \mathrm{ppm}$ of particulates in the emissions (approximately equivalent to $0.0025 \mathrm{grs} / \mathrm{scf})^{s}$

For a given application, the filtration velocity can be higher than that used for fabric filters, as the ceramic filter is permanently protected from dust penetration by the conditioned layer. With a fabric filter, pulse cleaning periodically strips away the protective layer, allowing particulate penetration of the media.

The combination of the filter's temperature resistance and its ability to withstand surges in volume means that barrier filters are less likely to be susceptible to damage caused by variable conditions and process upsets.

Ceramic monolithic candle filters were the first type of candle filters to be designed, manufactured, and tested in the hot gas cleanup program for coal gasification and PFBC gases. The three companies that provided these candle filters were:

- Refractron - Clay-Bonded Silicon Carbide: Silicon carbide grains held together with a claybased binder (Pall Corporation currently has a marketing license agreement with Refractron for sales of ceramic candle filters). 
- Coors - Alumina Mullite: A monolithic oxide ceramic, made up of mullite, anorthite, and alumina.

- Schumacher - Clay-Bonded Silicon Carbide: Silicon carbide grains held together with a claybased binder.

Ceramic fiber candle filters have been developed to provide materials that are more flexible than monolithic ceramics and do not fail in a brittle manner but are not as strong and are more susceptible to thermal shock. The composite material will not creep or be degraded by exposure to a hot gas cleanup environment. ${ }^{6}$ The filter suppliers for these materials are:

- $3 \mathrm{M}$ - CVI Silicon Carbide - Nextel Continuous Fiber Composite: Nextel (aluminosilicate) fibers with CVI silicon carbide coating. A carbon interface coating is used. Chopped fibers bonded with CVI SiC make up the filtration layer, which is held in place with an over wrap of CVI-coated fibers. This type was tested at PFBC conditions. Second-generation candle filters made of $3 \mathrm{M}$ CVI-SiC composite have also undergone testing at one of the Westinghouse hot gas filtration systems in Pittsburgh.

- B\&W - Continuous Fiber Ceramic Composite: Filament-wound alumina-based fiber, infiltrated with chopped fibers, which form the filtration surface. A program to develop a filament-wound alumina-based filter with a coating matrix of chopped ceramic fiber (Saffil) was initiated. Mitsui's ALMAX alumina fiber and 3M's NEXTEL 610 alumina fiber were used as the basis for the filters.

- DuPont - Lanxide PRD-66: An oxide ceramic material derived from wound fibers containing alumina, mullite, cordierite, and a glass phase. The microstructure is microcracked. A version of this type was tested at Tidd. Second-generation candle filters made of DuPont PRD-66 were developed and tested at one of the Westinghouse PFBC hot gas filtration systems in Pittsburgh.

- DuPont - Lanxide Silicon Carbide Composite: Silicon carbide fibers coated with CVI silicon carbide. A fiber interface coating is used, which is probably carbon. Chopped fibers make up the filtration surface. Second-generation candle filters made of DuPont SiC-SiC were tested at one of the Westinghouse PFBC hot gas filtration systems in Pittsburgh.

- Textron - Continuous Fiber Ceramic Composite: Filament-wound, Textron SCS-6 SiC fiber, nitride bonded silicon carbide composite. SCS-6 fiber surface provides appropriate mechanical properties. Difficulty in maintaining porosity and strength raised questions concerning the usefulness of this formulation.

- Westinghouse/Techniweave/3M - 3-D woven Nextel ${ }^{\mathrm{TM}}$ (aluminosilicate) fiber infiltrated with mullite using a sol gel process. A program to develop and test a fiber architecture and a fabrication process for a Nextel 550 based fiber-reinforced ceramic composite material was completed. 
- Industrial Filter \& Pump Fibrosics - Vacuum-formed chopped aluminosilicate fibers, having light weight and low strength. IF\&P has developed a lightweight modified aluminosilicate material (Fibrosic) that can be used for candles and other parts of the filter structure, such as tubesheets. Since the candles are much lighter than monolithic ceramic candles, the tubesheet can support candles made of Fibrosic but not of the heavier ceramics. IF\&P has developed a silicon carbide candle filter material that is stronger and can withstand higher thermal shock levels than the presently available aluminosilicate material.

- BWF America, Inc. - Alumina silicate fiber, or argillaceous earth silicate fiber ceramics. Alumina silicate fiber ceramic filter elements were designed and tested in power plant conditions (i.e., at low pressure) on three plants at temperatures of 650 to $920^{\circ} \mathrm{C}\left(1200^{\circ} \mathrm{F}\right.$ to $1690^{\circ} \mathrm{F}$ ) for up to 2,600 hours. The elements have also been tested on filtering other types of materials with similar results.

While work has centered on the development of candle filters, there is still interest in other devices such as ceramic tube filters, cross-flow filters, and sintered metal filters. Table 3-1 is an overview of developers and products. ${ }^{3}$ Not all of the system suppliers manufacture the filter elements used in their filter systems, and several manufacturers furnish only the filter elements.

Table 3-1

Overview of Particulate Control Device Developers

\begin{tabular}{|c|c|c|c|c|c|c|c|}
\hline & $\begin{array}{l}\text { Ceramic } \\
\text { Candle } \\
\text { System }\end{array}$ & $\begin{array}{l}\text { Ceramic } \\
\text { Candle } \\
\text { Element }\end{array}$ & $\begin{array}{c}\text { Ceramic } \\
\text { Fiber } \\
\text { Candle }\end{array}$ & $\begin{array}{l}\text { Ceramic } \\
\text { Tube }\end{array}$ & $\begin{array}{c}\text { Ceramic } \\
\text { Cross- } \\
\text { Flow }\end{array}$ & $\begin{array}{l}\text { Sintered } \\
\text { Metal }\end{array}$ & $\begin{array}{c}\text { Cross- } \\
\text { Flow } \\
\text { System }\end{array}$ \\
\hline Westinghouse & $x$ & & $X$ & & & & \\
\hline $\begin{array}{l}\text { USF/ } \\
\text { Schumacher }\end{array}$ & $X$ & $x$ & & & & & \\
\hline Pall & $x$ & & & & & $X$ & \\
\hline IF\&P & $X$ & & $X$ & & & & \\
\hline LLB & $x$ & & & & & & \\
\hline Refractrona & & $X$ & & & & & \\
\hline Coors & & $x$ & & & $x$ & & \\
\hline$\overline{3 M}$ & & & $X$ & & & & \\
\hline$B \& W$ & & & $x$ & $x$ & & & \\
\hline Lanxide & & & $x$ & & & & \\
\hline Textron & & & $x$ & & & & \\
\hline BFW & & & $x$ & & & & \\
\hline Asahi & & & & $\mathrm{X}$ & & & \\
\hline Blasch & & & & & $x$ & & \\
\hline CeraFilter & & & & & $\bar{x}$ & & $x$ \\
\hline
\end{tabular}

aRefractron is the sole supplier to Pall.

- Asahi Glass Co., Japan - The tube filter is typically made of porous cordierite. The tube elements are butted together to form 20-foot vertical units, and 9 to 85 of these units can be housed in a pressure vessel. The tube differs from a candle filter in that it requires mounting fixtures on both ends where they are butted together. There are tube sheets at the top and bottom of the butted tubes. Furthermore, in operation, the dirty gas enters at the top, then 
flows downward inside the tube at high velocity. Clean gas exits horizontally and outside the vessel through side outlets. A reverse pulse through the clean exit pipes using a venturi effect blows the Asahi tube filters back.

Ceramic cross-flow filters were developed to provide a hot gas cleanup device that could perform the same function as a candle filter, but in a smaller piece of equipment. The filter is made up of layers of porous ceramic laid in strips to create passageways. The gas inlet side strips are laid at $90^{\circ}$ to the gas outlet strips so that gas flows have to pass through a ceramic membrane to exit. By arranging the gas passageways in this manner, the utilization of space available is maximized.

- Westinghouse: Composed of alumina/mullite ceramic materials provided by Coors. Sheets and channels are placed in alternate layers at $90^{\circ}$ orientation in stacks and fired to produce a monolithic ceramic structure. Problems with delamitation of the ceramic strips have slowed the development of this type of filter by Westinghouse.

- Blasch: Owns a proprietary injection molding process, which can be used to fabricate a monolithic cross-flow filter. This filter is similar in design and function as the Coors crossflow filter manufactured for Westinghouse by Coors.

- CeraFilter: Similar to a cross-flow filter, the CeraFilter Ceramic Monolith Filter is a porous honeycomb monolith made from a Corning ceramic body and EX-80 cordierite material coated with a fine particle filtration layer. CeraFilter Systems is a joint venture between CeraMem Separations, Inc. and Foster Wheeler Energy International, Inc., formed in 1994 to use the background of both companies to develop hot gas cleaning systems for coal and biomass conversion processes.

Pall Corporation has developed metallic filters for high-temperature application. The two materials utilized are:

- Iron aluminide: Sintered metal iron aluminide. Alloy is resistant to corrosion by sulfur compounds.

- Stainless steels: Sintered stainless steel for application in IGCC downstream of a desulfurization system. Stainless filters were tested at the Waltz Mill gasifier. At an operating temperature of $675^{\circ} \mathrm{C}\left(1250^{\circ} \mathrm{F}\right)$ and with 600 to $3,000 \mathrm{ppm}$ sulfur, the filters failed. When tested with less than $30 \mathrm{ppm}$ sulfur in the gas stream, the filters performed satisfactorily.

\subsection{FUNDAMENTAL AND DESIGN ISSUES}

The fundamentals of particulate removal from gas streams have been studied, and equations have been formulated to predict filter performance. ${ }^{3}$ Above $500^{\circ} \mathrm{C}\left(932^{\circ} \mathrm{F}\right)$ there is less information; however, theoretically, the filters should perform similarly at high temperatures and pressures since they employ the same particle capture mechanisms. The capture mechanisms involved are:

- Interception 
- Diffusion

- Inertial impaction

- Gravitational settling

The most important physical characteristics of the particle relating to these capture mechanisms are density and diameter. Removing particulate from a high-temperature, high-pressure gas stream for physical characterization is difficult, but techniques have been developed to collect representative, isokinetic samples from these environments. In situ analysis is being developed using laser spark spectroscopy and Fourier transform infrared spectroscopy, providing another analysis technique. Real-time measurements will provide histories of alkali and particulate concentrations. However, it must be emphasized that many fundamental process parameters are not yet commonly available nor easily estimated by theoretical means.

There are two possible complications that can affect system performance for which no analytical mechanism exists: re-entrainment during blowback of barrier filters and penetration of particles due to bypassing, cracks, or construction defects.

After the particles are collected on barrier filters, they must be blown off and separated. In order for this to occur, the blowback pressure must be sufficient to stop the forward filtration of the dirty gas and exceed the cohesive force among the particles and the adhesive force between the particle or cake and the filter medium. This force is called "separation stress" and is a complex function of material, temperature, pressure, and the manner in which the particle is deposited. A fair amount of modeling and research has been done concerning separation of particles from barrier filters. The purpose of this modeling work was to find ways to reduce harmful effects of blowback on the ceramic filters.

\subsubsection{Pressure Drop Considerations}

The total pressure drop for a barrier filter consists of the following:

- The clean element pressure drop including the clean gas ductwork, which is a function of gas flow, density, and viscosity.

- The residue pressure drop, which is a result of "conditioning" the filter with a residual cake.

- The filter cake pressure drop, which is a function of the cake permeability as it builds up on the filter element.

The filter pressure drop affects equipment size (capital cost), operating efficiency, and maintenance costs. Because of the high operating pressure of advanced combustion systems being developed by the DOE, it is not a significant factor. However, for low-pressure applications, pressure drop becomes a critical design consideration.

Filter cake pressure drop can be predicted if data such as particle size distribution, loading, and cake porosity are available. A serious problem is that there is not much data for particles and filter cakes that can be used in these theoretical equations. Both the DOE and industry are 
addressing this issue in the clean coal technology demonstration programs. Determining filter cake pressure drop will allow calculations of blowback cleaning requirements and cake cleaning efficiency. This information can be used to optimize the design and operation of blowback systems.

\subsubsection{Barrier Filter Design Considerations}

Candles are typically hung vertically from the top of each candle, from a horizontal tubesheet. One recent design supports them from the bottom. Various methods are used to secure the candles to the tubesheet, including weights, clamps, and springs. Care must be used in making this connection, since there is a pressure differential across the connection that may cause leaks across the tube to tubesheet seal, as well as the effects of absolute and differential expansion and thermal and mechanical shock during cleaning.

Candles are cleaned by sending a surge of air or inert gas backward through the candle wall. Experience to date has shown that a "pulse" system, wherein a short, high-pressure pulse of gas is injected on the clean side of the candle, apparently works better than a back flow system, where a lower pressure, longer back flow of gas is used. Systems where isolation of elements for cleaning is used require extra filter elements, increasing the filter system costs. Also, the gas used for pulse cleaning is usually much cooler than the filter element, and can cause thermal stress on the elements. However, regenerators have been developed that provide mass thermal storage, so that the back-pulse gas is prewarmed prior to entering the candle element.

A new, clean filter has an intrinsic pressure drop that is a function of face velocity. As the filter is subjected to normal use and cleaning cycles, the pressure drop across the filter will build up until it reaches equilibrium, which will normally be around twice the initial clean pressure drop at equal face velocity (see Figure 3-1). The value of the equilibrium pressure drop is important to the design of the filter as well as the rest of the plant, and should be determined by testing of actual dust, if possible, before final design.

Figure 3-1

Differential Pressure Versus Time

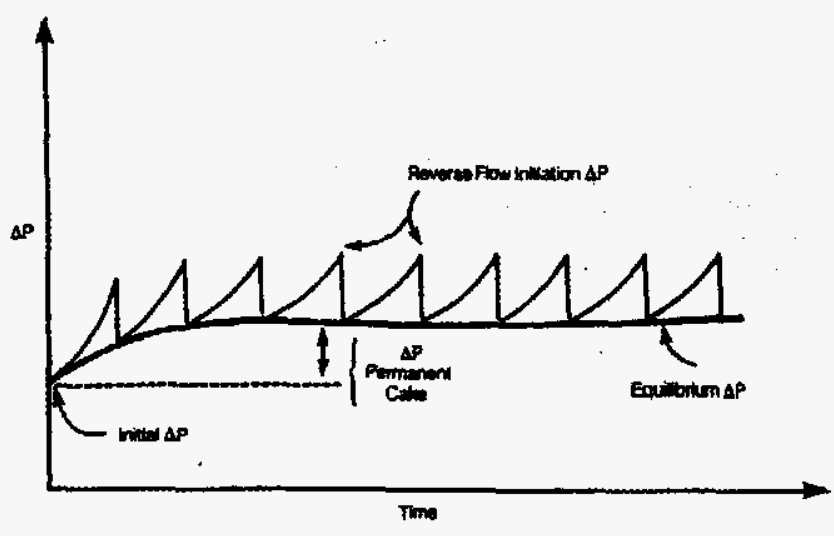


Pressure drop across the candle filter wall can be controlled in several different ways. By varying the wall thickness, the pressure will vary substantially, assuming other factors are held constant. However, wall thickness may be dictated by strength requirements and may not be variable. Porosity can also be varied. Some filters are manufactured with more than one layer, each with a different pore size, the outer layer or skin with smaller pores to prevent small particles from entering the pores.

Although the upper temperature limit of ceramic filters is high, 1200 to $1500^{\circ} \mathrm{F}$, there are technical difficulties in operating at these limits. Special consideration must be given to the design and construction of the filter housing, and often the dusts being filtered have different characteristics at these elevated temperatures. Certain types of ash can sinter at temperatures as low as $1200^{\circ} \mathrm{F}$. A sintered or melted material on a rigid media could present significant difficulties when pulse cleaning.

Ceramic filter elements possess sufficient strength to withstand repeated pulse cleaning. However, they are susceptible to erosion by direct impingement by abrasive particles. Proper filter design can eliminate the threat from "shot blasting" of the elements.

In certain situations, the ceramic filters can be prone to sticky ash or flux attack. If a substantial amount of combustible material and flux is allowed to build up on the filter element, then sintering and weakening of the element can occur.

The DOE development program is aimed at applications that operate at higher temperature (1200 to $1500^{\circ} \mathrm{F}$ ) and pressure (10 to $25 \mathrm{~atm}$ ) than most industrial applications. Critical filter material properties at these conditions are tensile strength retention and tensile creep, or microcrack stability. A coordinated program is in place to resolve these fundamental technical issues. This program has led to recent advances in filter element development and feeds into pilot plant testing and demonstration programs. Progress has been reported in both reducing creep above $760^{\circ} \mathrm{C}$ ( $1400^{\circ} \mathrm{F}$ ) and increasing the $\Delta \mathrm{T}$ for microcracking. ${ }^{7}$

A significant number of ceramic filters have broken in various DOE experimental and demonstration devices tested at Tidd and the PSDF. Some of the lessons learned include:

- Nearly all of the candle breakage observed at Tidd was attributed to ash bridging in the filter. Ash bridging was strongly affected by the size and temperature of the ash entering the filter. Ash from a partially detuned cyclone (about 7 microns) was more easily removed than the smaller ash, but still difficult to remove at operating temperatures over $790^{\circ} \mathrm{C}\left(1450^{\circ} \mathrm{F}\right)$. Ash above a mass mean diameter of 27 microns was easily removed and did not tend to bridge. ${ }^{8}$

- Nearly all of the candle breakage observed at the PSDF was attributed to initial operation of the developmental transport reactor and the transition from propane to coal during startup. ${ }^{5}$

- It is important to prevent ash from entering the inside of the filter candles to avoid blinding them on the inside surfaces. Also, ash accumulation in the inside bottom of candles can induce cracking in the candles. 
- It is important to have reliable continuous ash removal from the filter. Ash buildup in the particulate filter hopper resulted in candle breakage.

\subsection{BARRIER FILTER MARKETS}

In general, barrier filters fill niche markets with special problems. They do not compete in the typical particulate control market against conventional technology, i.e., electrostatic precipitators or fabric filters/baghouses. Barrier filters must be seen as a system offering the user an incentive to justify the higher initial costs for the filters. Table 3-2 lists applications cited for barrier filters. ${ }^{9}$

Table 3-2

Barrier Filter Applications Cited

\begin{tabular}{||l|l|l|l||}
\hline $\begin{array}{c}\text { Source: Ceramic Gas } \\
\text { Cleaning }\end{array}$ & $\begin{array}{c}\text { Source: Industrial Filter \& } \\
\text { Pump Mfg Co. }\end{array}$ & \multicolumn{1}{|c|}{ Source: Cerel Ltd. } & $\begin{array}{c}\text { Source: Filter Media } \\
\text { Consulting, Inc. }\end{array}$ \\
\hline Fluidized Bed Combustion & Alumina Scrap Smelting & Gasification of Biomass & IGCC \\
\hline Diesel Exhaust & Brass and Copper Smelting & Zirconia Production & PFBC \\
\hline Wood Gasifier & Lead Smelting & Fumace Melting Lead & Calcination \\
\hline Fumed Silica & Zirconia Processing & Aluminum Scrap Melting & Catalyst Recovery \\
\hline Bitumen Oil Mist & Metal Oxide Powder & Foundry Applications & Material Recovery \\
\hline Clinical Waste Incinerator & Wood Bark Incineration & Smokeless Fuel Production & Chemical Industry \\
\hline RDF Incinerator & Clinical Waste Incinerator & Machine Tool Dust Removal & Catalytic Cracking \\
\hline & Chemical Wastes & Clinical Waste Incineration & Waste Incineration \\
\hline & Hazardous Wastes & Chemical Waste Incineration & \\
\hline & Soil Remediation & & \\
\hline
\end{tabular}

There have been several filters supplied for use in PFBC and IGCC applications in the DOE Clean Coal Technology Demonstration Program. These have included:

- Westinghouse supplied the filter at Tidd. The filter tested at Tidd had three clusters with three tiers each and contained over 350 candles. A similar size vessel using a maximum of 273 candles is to be tested at Wilsonville on a PFBC combustor. Westinghouse also provided the ceramic candle filters for the 95 MWe Piñon Pine IGCC project. Westinghouse has an agreement with Foster Wheeler to design and supply filters for their PFBC clean coal demonstration plants.

- Pall supplied a 56-candle filter that was to be tested at the Tampa Electric Company IGCC plant on a slipstream of fuel gas downstream of the hot gas desulfurization system. Sintered metal candles were to be tested. 


\subsection{EXPERIENCE IN SIMILAR SERVICE AS SUPERIOR GRAPHITE}

The Superior Graphite filter application will be unique due to its large size (designed for $40,000 \mathrm{acfm}$ ), the high percentage of carbon in the particulate $(>75 \%)$, and the relatively high oxygen content $(18 \%)$ when compared to flue gas. Candle filters have been used to filter high carbon particulate ${ }^{4,10}$, but generally not at this size range. The application most similar to Superior Graphite was described in a paper at the Second International Symposium on Gas Cleaning at High Temperatures. ${ }^{11}$

Solid smokeless fuel was manufactured at Coal Products Coventry Homefire Works by a process involving the low-temperature fluidized-bed carbonization of crushed coal. The waste gas produced by this process, amounting to some $17,000 \mathrm{Nm}^{3} / \mathrm{h}(10,000 \mathrm{scfm})$ and containing large quantities of tar and fine carbonized coal particles (char), was previously incinerated, and its products of combustion discharged to the atmosphere via a 65-meter (213-foot)-high chimney, resulting in a heavily ash-laden emission.

Even though low-density ceramic filtration had not been employed in any major flue gas cleaning scheme and little practical information was available, the Company considered the technique worth evaluating in the absence of more conventional solutions. In late 1990, a pilot ceramic filter was purchased with the aim of cleaning a side stream of flue gas from the incinerator chimney.

The imposition in June 1991 of a two-part Improvement Order by Her Majesty's Inspectorate of Pollution on the particulate emissions from the incinerator chimney required the fitting of suitable filters to the flue gas ducts of both Works boilers.

The first of the boiler ceramic filters, for the No. 1 boiler, was designed in the light of experience gained in the pilot filter operations. This filter was capable of handling $50,000 \mathrm{Am}^{3} / \mathrm{h}$ $(30,000 \mathrm{acfm})$ of boiler flue gas at a normal operating temperature of $270^{\circ} \mathrm{C}\left(518^{\circ} \mathrm{F}\right)$ and was designed to operate at a maximum temperature of $400^{\circ} \mathrm{C}\left(752^{\circ} \mathrm{F}\right)$. The expected operating pressure drop was 180 to $250 \mathrm{~mm}$ ( 7 to 10 inches) $\mathrm{H}_{2} \mathrm{O}$. The filter house contained 2,592 Cerafil S elements mounted in 72, 36-element, horizontal cassettes.

The filter on No. 1 boiler was commissioned in October 1991. Failures initially occurred in the filter due to the combustion and sintering of high-carbon dust following boiler flame failure, requiring the complete replacement of the ceramic elements. Test rig work indicated that combustion did not occur in the dust at temperatures below $250^{\circ} \mathrm{C}$ irrespective of oxygen levels or carbon contents, and at temperatures above $250^{\circ} \mathrm{C}$, combustion was not observed at oxygen levels less than $16 \% .{ }^{11}$ After this test program, the following recommendations were implemented for both filters in July 1992:

- A reduction in both temperature and oxygen content of the flue gas.

- The isolation of the filter immediately following boiler flame failure and the blanketing of the unit with nitrogen. 
Filters were subsequently operated on both boilers with only occasional occurrences of ash combustion and sintering following boiler flame failure till mid-1995. At that time the Works switched to a cold process and shut down the hot process facility.

The authors' conclusion about the use of barrier filters, as quoted below, probably holds true for any large scale-application, including the Superior Graphite application.

"The use of small multi-element pilot filter units are an essential stage in determining the suitability of low-density ceramic filters for large scale gas cleanup projects. The analysis of the data obtained during prolonged testing of such filters can give valuable insights into the behaviour of the materials being filtered and provides information necessary for the finalisation of the design of full size units. Even so, problems not encountered even during extensive pilot filter trials, can arise during the operation of full stream units causing possible radical re-design and unexpected expense." 11 


\subsection{SUPERIOR GRAPHITE'S BARRIER FILTER SYSTEM DESIGN}

\subsection{KICKOFF MEETING}

A kickoff meeting was held at the plant on November 18, 1999. The following ground rules were discussed and agreed upon:

- Locate the filter downstream of the afterburners/gas coolers. Filtering upstream of the afterburner would require filters for each furnace and may not prove completely safe due to the requirements of cooling the combustible gases from the furnaces before filtering.

- Retain, as much as possible, present operating conditions. Changes that affect flows and temperatures, such as the amount of dilution air, would affect the operation of the downstream scrubber.

- The CRADA design conditions will be based on the design production rate temperatures, flows, and loadings. These are based on five furnaces operating. The numbers were verified by Superior Graphite.

- The present cyclone will be retained as a backup to the new filter.

The following issues were also discussed:

- Fan upgrade/replacement - A maximum of 7 inches of water is available with the existing fans. Since the expected pressure drop requirements for the barrier filter will likely exceed this and Superior Graphite would like some margin, fan upgrades or replacement is anticipated.

- Controls upgrade and integration.

- Turndown - Superior Graphite operates anywhere from one to five furnaces. The filter must accommodate the varying flow.

- Capacity factor - Superior Graphite operates 24 hours a day, 365 days a year without any general plant shutdown. Individual furnaces are shut down every 7 to 30 days.

- Upsets - Periodically a major furnace upset occurs, which ejects high-temperature, heavily loaded gas through the cyclone.

- Blowback gas - Nitrogen is available if necessary.

- Space - There is no spare space in the existing furnace building. An adjacent scrubber building has a vacant bay that could accommodate the filter.

- Particulate matter characteristics - Only limited data exist on the particulate matter size distribution and physical characteristics from sampling of the existing particulate collected 
from existing control devices. No in-line sampling of particulate was conducted as a part of this conceptual study.

Based on the agreed-upon ground rules and these discussions, a functional specification was prepared and a request for a budget estimate was sent to several vendors. The responses were used as the basis for the conceptual design.

\subsection{HOPKINSVILLE PLANT PROCESS DESCRIPTION}

The Hopkinsville plant process begins with graphite furnaces, which are fed calcined petroleum coke to produce a high purity carbon product. Operating at temperatures exceeding $2760^{\circ} \mathrm{C}$ $\left(5000^{\circ} \mathrm{F}\right)$, this process converts amorphous carbon to graphite and generates a flue gas containing $\mathrm{N}_{2}, \mathrm{CO}, \mathrm{H}_{2} \mathrm{~S}$, and other sulfur compounds, along with particulate matter emissions. Gases exit the furnaces at temperatures on the order of $1980^{\circ} \mathrm{C}\left(3600^{\circ} \mathrm{F}\right)$.

Above each furnace is an afterburner that by air infiltration oxidizes the $\mathrm{CO}$ to $\mathrm{CO}_{2}$ and the $\mathrm{H}_{2} \mathrm{~S}$ to $\mathrm{SO}_{2}$ (and some $\mathrm{SO}_{3}$ ). At the exit of the afterburner, the total design gas flow is 35,700 pounds per hour at a temperature of about $800^{\circ} \mathrm{C}$. The operating pressure at the furnace exit is $1 / 2$ inch of water below atmospheric, as a result of the induced draft (ID) fans downstream of the particulate removal processes. There is a port at the inlet end of the afterburner. Air enters the port as part of the afterburner oxygen for combustion.

The gases coming from each afterburner are cooled by diluting with air. Ambient air is drawn into each furnace duct through a damper. Total dilution air added to the afterburner gas at design conditions is 48,300 pounds per hour. With this dilution air, the gases are cooled by mixing to $350^{\circ} \mathrm{C}\left(662^{\circ} \mathrm{F}\right)$ design temperature. In operation, the actual temperature range is 250 to $325^{\circ} \mathrm{C}$ $\left(480\right.$ to $\left.620^{\circ} \mathrm{F}\right)$, with excursions to $375^{\circ} \mathrm{C}\left(707^{\circ} \mathrm{F}\right)$.

Table 4-1

Afterburner Gas Composition at Design Conditions

\begin{tabular}{||l|c|c|c|}
\hline & Lb/hour & Lbmoles/hour & Mole Fraction \\
\hline Nitrogen & 27,300 & 975 & 0.807 \\
\hline Oxygen & 5,700 & 178 & 0.148 \\
\hline Carbon Dioxide & 1,020 & 23 & 0.019 \\
\hline Sulfur Dioxide & 1,250 & 20 & 0.016 \\
\hline Sulfur Trioxide & 17 & 0.2 & 0.0002 \\
\hline Water & 200 & 11 & 0.010 \\
\hline Particulates (est) & 220 & N/A & N/A \\
\hline Total & 35,700 & 1,207 & 1.00 \\
\hline
\end{tabular}


Table 4-2

Diluted and Cooled Gas Composition at Design Conditions

\begin{tabular}{||l|c|c|c||}
\hline & Lb/hour & Lbmoles/hour & Mole Fraction \\
\hline Nitrogen & 64,000 & 2,286 & 0.791 \\
\hline Oxygen & 16,800 & 525 & 0.182 \\
\hline Carbon Dioxide & 1,100 & 25 & 0.008 \\
\hline Sulfur Dioxide & 1,250 & 20 & 0.007 \\
\hline Sulfur Trioxide & 17 & 0.2 & 0.00008 \\
\hline Water & 633 & 35 & 0.012 \\
\hline Particulates (est.) & 220 & N/A & N/A \\
\hline Total & 84,000 & 2,891 & 1.00 \\
\hline
\end{tabular}

As shown in the flow diagram (Figure 4-1), the cooled afterburner lines are then manifolded together where operation under two separate permits allows alternative particulate and sulfur removal.

Figure 4-1

Plant Flow Diagram

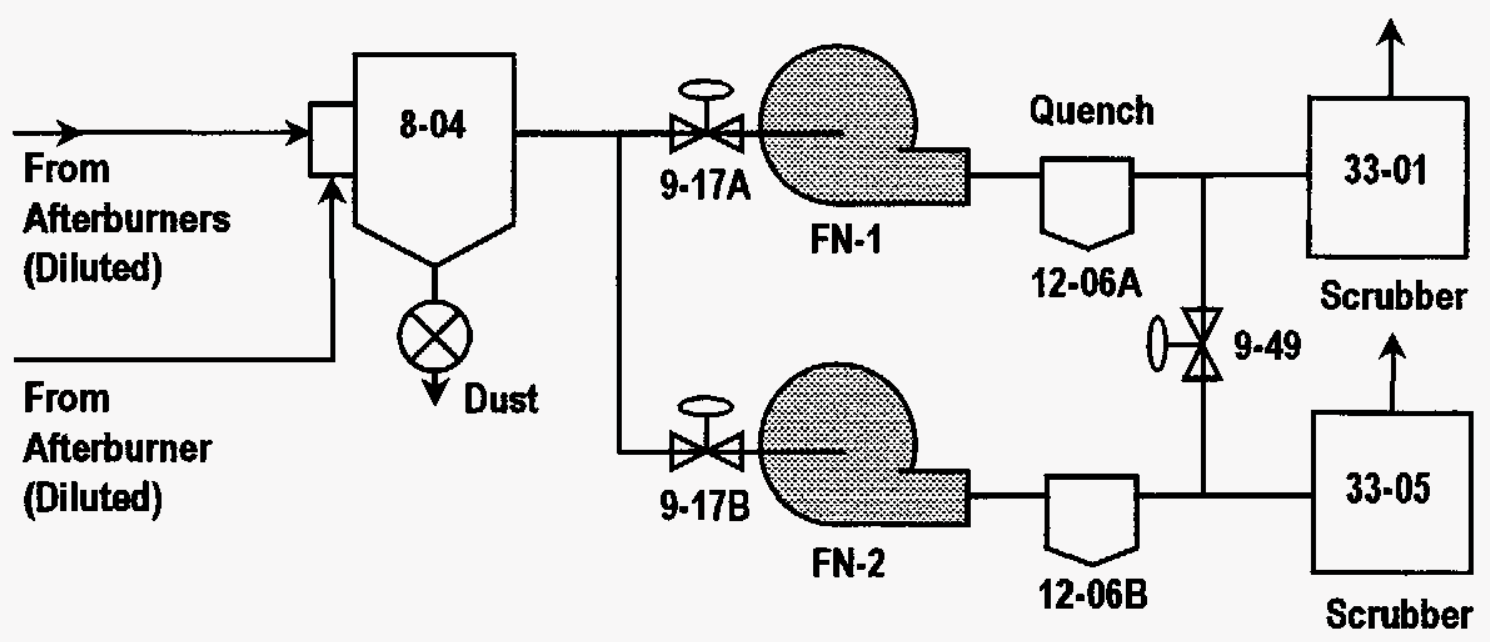

For the first permitted alternative, the gas exits in a direction perpendicular to the manifold to an ID fan and a baghouse. Only one of the furnaces is permitted to process sulfur-bearing raw material while discharging to the baghouse. The baghouse is also used with specialty production.

The second permitted alternative for particulate and sulfur removal is located at the end where the manifold terminates. The 30-inch-diameter duct passes through the wall of the furnace room to be joined with another furnace duct at the entrance to the particulate removal multiclone.

At this point, the estimated gas flow is in the range of $40,000 \mathrm{acfm}$ at $350^{\circ} \mathrm{C}\left(662^{\circ} \mathrm{F}\right)$ operating at maximum conditions. The multiclone consists of 48 cyclones and has a total pressure drop of about 2 to 3 inches $\mathrm{H}_{2} \mathrm{O}$. The multiclone occupies a 12 foot $\times 15$ foot $\times 35$ foot high bay in the building. Ducts run from the multiclone to a duct, which is split to the two ID fans. The new ID fan outlet is ducted to the new quench/scrubber, and the old fan outlet is ducted to the old quench 
scrubber. A duct with a damper connecting the quench outlets permits operation of both fans through a common scrubber. The old scrubber is retained as a backup to the new scrubber. Operating temperature of the multiclone is limited to $350^{\circ} \mathrm{C}\left(662{ }^{\circ} \mathrm{F}\right)$ due to the upper limit on the ID fans. The fans are outside the multiclone building and direct gas to the quench scrubbers.

Gas entering the quench is cooled with scrubber liquor to $63^{\circ} \mathrm{C}\left(145^{\circ} \mathrm{F}\right)$. Both the old and new scrubbers have rotary atomizers and a number of mist eliminators. The old scrubber is permitted at $95 \% \mathrm{SO}_{2}$ efficiency, and the new scrubber is permitted at $97.5 \% \mathrm{SO}_{2}$ efficiency.

The new scrubber is located in a scrubber building, and occupies about half of the area. The unoccupied area of the scrubber building has an open bay area about 25 feet $\times 20$ feet $\times 30$ feet high, which could be suitable for the new filter.

\subsection{TECHNICAL ISSUES}

Several technical issues that are pertinent to the design of the barrier filter for Superior Graphite are discussed below.

Face Velocity - A new, clean filter has an intrinsic pressure drop that is a function of face velocity and the filter media. As the filter is subjected to normal use and cleaning cycles, the pressure drop across the filter will build up until it reaches equilibrium. Too high a face velocity can result in several problems including dust re-entrainment, unstable equilibrium pressure drop, or dust penetration of the filter element. Too low a face velocity increases the size/cost of the filter.

The value of the face velocity is important to the design of the filter as well as the rest of the plant, and should be determined by testing of actual dust, if possible, before final design. In this conceptual design study, the vendors used their judgment and experience to select a face velocity.

Carbon Content of Ash - Failures occurred in the Coventry Homefire Works filter due to the combustion and sintering of high carbon dust following boiler flame failure, allowing unburned carbonization dust into the filter. The Superior Graphite's carbon content of the dust and oxygen content of the flue gas would be similar to the Coventry Homefire Works during boiler flame failure but would be afterburned, thereby being free of volatiles. Whether Superior Graphite's dust will be susceptible to combustion and sintering must be determined by testing. Periodically an upset in a furnace at Superior Graphite will cause the contents to be blown through to the filter. For this reason, the design does include the ability to isolate the filter during upsets and the blanketing of the unit with nitrogen.

Particle Loading and Size - With the multiclone at Superior Graphite bypassed, the particulate loading was estimated at 0.6 grains/acf with a mass mean diameter of 34 microns. Using dilution air to cool the flue gas results in lower loadings than from a typical flue gas. The typical loading at Coventry Homefire Work's filter was 3.0 grains/acf. Lower loadings result in longer blowback cycles and less dust handling. 
Operating experience has shown that a coarser particle size distribution is more easily removed. At Tidd, ash from a partially detuned cyclone (about 7 microns) was more easily removed than the smaller ash, but still difficult to remove at operating temperatures over $790^{\circ} \mathrm{C}\left(1450^{\circ} \mathrm{F}\right)$. Ash above a mass mean diameter of 27 microns was easily removed and did not tend to bridge. ${ }^{8}$ At the PFBC plant in Wakamatsu, the cyclones have been completely removed since coarse particles are easier to filter. ${ }^{12}$

Sticky Ash or Flux Attack - The major causes of sticky ashes are eutectics caused by alkalis in the ash. At Tidd, high alkali coal ashes above $1500^{\circ} \mathrm{F}$ in oxidizing conditions resulted in sticky ash and bridging. ${ }^{8}$ The petroleum coke ashes are low in alkali. Alkali concentrations in coal ash range from 2 to $3 \%$, whereas alkali in coke ash ranges from nil to $<1 \%$. Also, the ppm level of alkali from coke combustion compared to coal combustion is one to two orders of magnitude lower, due to the low ash concentration $(<1 \%)$ in coke. Operating in an oxidizing condition below $1300^{\circ} \mathrm{F}$ should preclude sticky solids.

Candle Breakage - Candle filter elements, being rigid, can also be susceptible to brittle failure, especially at the high temperatures and pressures used in PFBC and IGCC power generation. A significant number of ceramic filters have broken in various DOE experimental and demonstration devices tested at Tidd and the PSDF. Nearly all of the candle breakage observed at Tidd was attributed to ash bridging in the filter, ${ }^{8}$ and at the PSDF it was attributed to initial operation of the developmental transport reactor and the transition from propane to coal during startup. ${ }^{5}$ Other root causes of failures include ash removal from pressurized systems and sintering of the candles. Superior Graphite, operating at relatively low temperature and pressure, should be able to control many of these root causes.

Ability to Remove $\mathrm{SO}_{3}$ - High levels of $\mathrm{SO}_{3}$ passing into wet scrubbers have been shown to cause acid mist carryover and potential stack opacity problems. ${ }^{13}$ Two potential causes of the opacity problem at Superior Graphite are particulate passing through the multiclone and a relatively high $\mathrm{SO}_{3}$ concentration in the flue gas $(80 \mathrm{ppm})$. The barrier filter will reduce particulate carryover. However, there is expected to be little $\mathrm{SO}_{3}$ removed by the filter without the addition of separate absorbent material. Some test work has been done on injecting absorbents into barrier filters for $\mathrm{SO}_{3}$ removal, ${ }^{14}$ but little if any commercial experience is available.

Pilot Plant Testing - The Superior Graphite filter application will be unique due to its large size (designed for $40,000 \mathrm{acfm}$ ), the high percentage of carbon in the particulate $(>75 \%)$, and the relatively high oxygen content $(18 \%)$ when compared to flue gas. While guidance can be obtained from the design and operation of the Coventry Homefire Works filter, there are enough differences (coal versus coke as a carbon source, flue gas versus dilution gas, 30,000 acfm versus $40,000 \mathrm{acfm}$ ) that it would be prudent to run pilot plant tests on the Superior Graphite dust. The use of small multi-element pilot filters in a slipstream at the Hopkinsville plant can give valuable insights into the behavior of material being filtered and provides information necessary for the finalization of the design of full-size units. ${ }^{11}$ 
An objective of the pilot plant tests would be to verify for a particular filter media the face velocity that can be used while maintaining a stable pressure drop without dust re-entrainment or penetration. A second objective would be to determine the conditions necessary for preventing the combustion of solids on the filter elements in Superior Graphite's outlet gases.

Capacity - Typical barrier filters in industrial applications usually filter gas streams of less than $10,000 \mathrm{acfm}$. However, several larger sized units have been built, with the largest a $2 \mathrm{x}$ $54,000 \mathrm{acfm}$ at the PFBC unit in Wakamatsu, Japan. The Superior Graphite unit, at 40,000 acfm, will be one of the largest units built.

Reliability - In the past, reliability has been an issue with barrier filters, but much has been learned. At the Coventry Homefire Works, after an initial period of candle failures during upset conditions, reliable operation of the filters was obtained for several years before the process shut down. Superior Graphite's operating conditions are not severe for barrier filters. Particulate loading, temperature, and face velocity under typical operating conditions are not particularly high for this type of filter. Under normal operating conditions, reliability should be maintained. However, most candle failures occur during abnormal operating conditions such as startup, shutdown, and upsets. Superior Graphite will be as susceptible to these as others.

\subsection{BARRIER FILTRATION SYSTEM PROCESS DESIGN}

Referring to the block flow diagram of Figure 4-2, the existing multiclone will be retained as a parallel backup particulate control device. The filter retrofit ductwork will join the off-gas manifold with insertion of a cross before it exits the furnace building. Between the cross and the existing multiclone, a man-safe wafer damper (V-1) will be used to isolate the multiclone during filter operation. All furnace ducts will be re-routed to join the cross. Downstream of the multiclone, in the duct coming from the multiclone building, another wafer damper (V-2) will be installed to achieve complete isolation of the multiclone. Man-safe wafer dampers are leak-proof butterfly-type dampers, sealed with external air pressurization. The man-safe designation entails preventing escape of toxic gases into a confined area.

At the cross on the multiclone inlet, the left stub ductwork will be routed through the walls to reach the bay of the scrubber building. The filter vessel (F-1) will be installed in the scrubber building high bay. At the duct entering the filter vessel, a wafer damper (V-3) will be installed, and at the filter exit, a second wafer damper (V-4) will be installed. These valves will be used to isolate the filter. The filter system will be designed with an active protection system, which senses high temperatures, closes the isolation valves, opens the multiclone valves, and purges the filter vessel with nitrogen. The purpose of using nitrogen is to reduce the oxygen level and quench any combustion that could start within the filter vessel. The valves can also isolate the filter vessel for periodic maintenance. During maintenance, the filter vessel will be purged with air, and confined entry procedures will be in effect. Nitrogen and air are supplied from a high-pressure feed line through a control valve. The filter outlet will be ducted outside to the ID fans' common suction line. 
Figure 4-2

Barrier Filter System

Block Flow Diagram

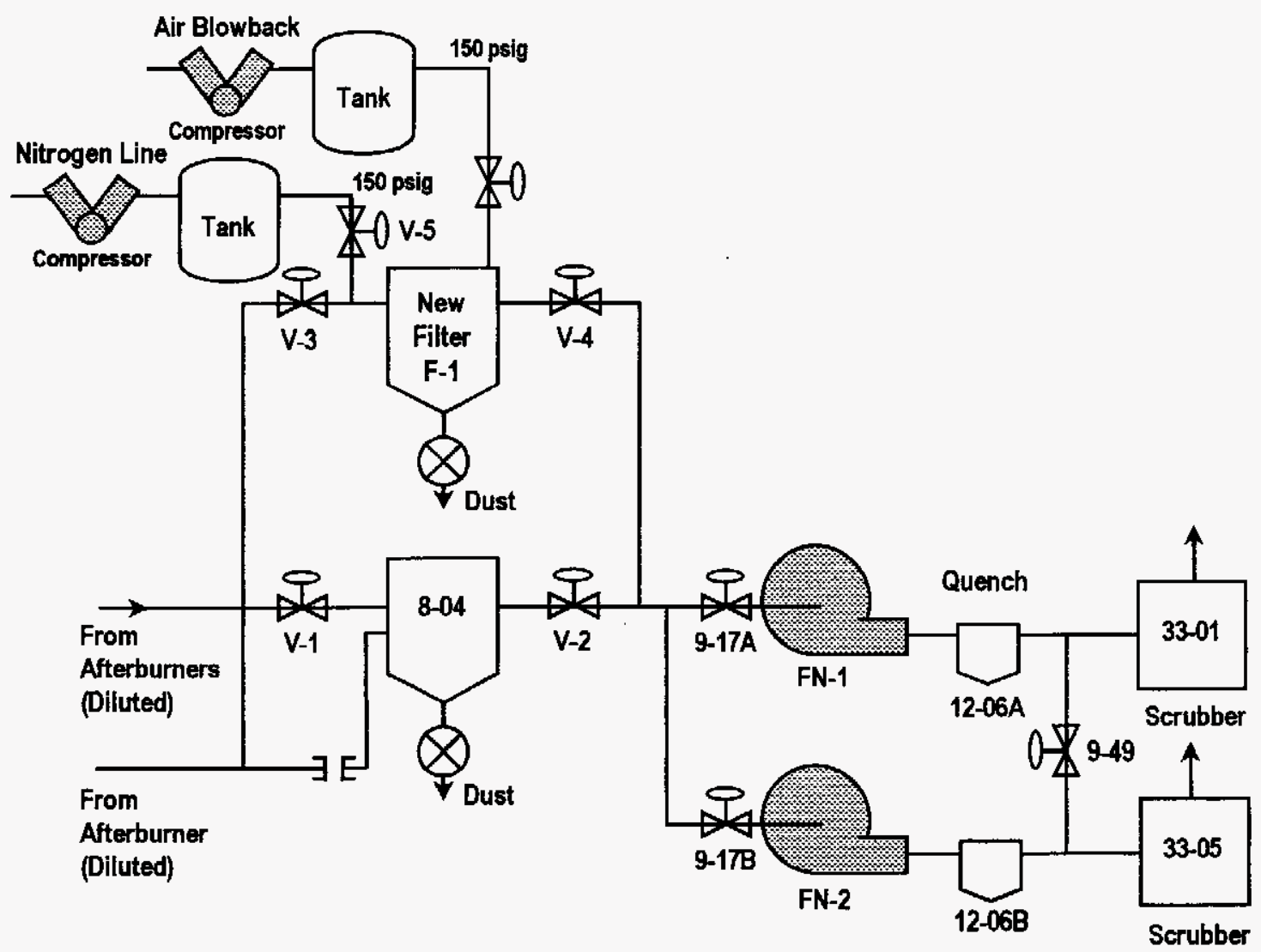

Dust collected by the barrier filter will be removed from the bottom cone of the filter vessel by screw conveyor operation. Filter dust will be conveyed to a closed bin, which is outside and underneath the adjacent bag house. Periodically the bin contents will be disposed off site.

Immediately downstream of the valve in the ductwork coming from the existing multiclone, a tee will be installed in the common suction line for the dual ID fans (FN-1, FN-2). The tee stub will be joined with the duct leading from the filter vessel contained in the scrubber building.

This retrofit design provides the following capabilities:

- Retain existing multiclone as a backup for the filter.

- Isolate the filter for maintenance.

- Sense upsets, isolate the filter, and purge with nitrogen.

- Retain existing duct configuration downstream of filters to ID fans.

- Retain dual ID fans with flexibility in turndown.

- Provide dual quench capability.

- Retain the old quench/scrubber for system backup. 


\subsection{FILTER EVALUATION}

A functional specification and a request for a budget estimate were sent to four vendors.

Responses were received from three vendors proposing to utilize candle filters for this application. This section provides a review of the vendors' response and a rationale for the selection of the filter used in the conceptual design.

\subsubsection{Particulate Filter Functional Specification}

Capacity Factor

Installation Location

Gas Flow

Gas Composition

Pressure

Temperature

Blowback

Inerting Provisions

Maintenance Provisions

Filter System I\&C
Plant operates 24 hours a day, 365 days a year

Indoor location in scrubber building, two bays about 15 feet $\mathrm{x}$ 15 feet $\times 30$ feet high

$84,000 \mathrm{lb} /$ hour, $220 \mathrm{lb} /$ hour particulates, 0.6 grains/acf

$\begin{array}{ll}\text { Nitrogen } & 0.791 \text { mole fraction } \\ \text { Oxygen } & 0.182 \text { mole fraction } \\ \mathrm{CO}_{2} & 0.008 \text { mole fraction } \\ \mathrm{SO}_{2} & 0.007 \text { mole fraction } \\ \mathrm{SO}_{3} & 0.00008 \text { (80 ppmv) } \\ \mathrm{H}_{2} \mathrm{O} & 0.012 \text { mole fraction }\end{array}$

Inlet @ 2 inches w.g. negative

Design temperature $350^{\circ} \mathrm{C}\left(662^{\circ} \mathrm{F}\right)$

Normal operating 250 to $325^{\circ} \mathrm{C}\left(480\right.$ to $\left.620^{\circ} \mathrm{F}\right)$

Excursions to $375^{\circ} \mathrm{C}\left(707^{\circ} \mathrm{F}\right)$

Particulate Characteristics Granular, $>75 \%$ carbon, balance ash

Particulate Distribution $\quad 95 \% \quad<66$ micron

$90 \% \quad<56$ micron

$80 \%<50$ micron

$50 \%<34$ micron

$25 \%<10.5$ micron

$10 \%<6.5$ micron

100 psig air (blowback gas supplied by others)

Nitrogen as required (nitrogen supplied by others)

Air purging and confined entry protection

a) As supplied with filter 
b) Temperature excursion monitors directing isolation valve closure and vessel flooding with inerting gas.

Material Considerations

Sulfuric acid dew point estimated at $160^{\circ} \mathrm{C}\left(320^{\circ} \mathrm{F}\right)$

\subsubsection{Particulate Filter Selection}

Table 4-3 shows a summary of the budget estimate received from the vendors. Responses were received from three of the four vendors solicited.

Table 4-3

Filter Data Summary

\begin{tabular}{|c|c|c|c|}
\hline Vendor & No. 1 & No. 2 & No. 3 \\
\hline Type & Candle & Candle & Candle \\
\hline Material & Aluminosilicate & SS $316 \mathrm{~L}$ & Silicon carbide \\
\hline Element Size & $60 / 40 \times 1500 \mathrm{~mm}$ & 100 in $L$ & $60 / 40 \times 1500 \mathrm{~mm}$ \\
\hline Face Velocity, feet per minute & 8 & 6 & 5.5 \\
\hline ACFM/Candle & 24 & 18 & 16.6 \\
\hline Number & 1,632 & 2,088 & 2,400 \\
\hline Estimated Candle Life & 3 years & 3 years & 15,000 hours \\
\hline Delta $P$, inches w.g. & 20 & 15 & 18 \\
\hline Performance & $99.9 \%$ & $<1 \mathrm{ppm}$ & $<5 \mathrm{mg} / \mathrm{Nm}^{3}$ \\
\hline Number of Filter Vessels & 1 & 2 & 2 \\
\hline$H$, feet & 15 & 35 & 14 \\
\hline$L$, feet & 20 & & 21 \\
\hline$W$, feet & 13 & 9 dia & 14 \\
\hline Cost & $\$ 907,063$ & $\$ 2,500,000$ & $\$ 1,338,733$ \\
\hline Exclusions & $\begin{array}{c}\text { Shipping } \\
\text { Field Erection } \\
\text { Service Platform } \\
\text { Startup } \\
\text { Spares }\end{array}$ & Insulation & $\begin{array}{c}\text { Insulation } \\
\text { Supporting Structure } \\
\text { Service Platform } \\
\text { Field Erection } \\
\text { Startup, Spares }\end{array}$ \\
\hline
\end{tabular}

Vendor 1 proposed using candles manufactured from low-density vacuum formed chopped aluminosilicate fibers. At their proposed face velocity of $8 \mathrm{feet} / \mathrm{minute}$, the number of filter elements required would be 1,632 . These would be packaged into a single filter housing approximately 20 feet $\times 13$ feet $\times 15$ feet high.

Vendor 2 proposed using candles manufactured from a classified process to create a seamless, porous stainless steel membrane. At their proposed face velocity of 6 feet/minute, the number of filter elements required would be 2,088 . These would be packaged into two filters approximately 9 feet in diameter $\times 35$ feet high. 
Vendor 3 proposed using candles manufactured from a coarse porous support body of silicon carbide ceramically bonded with a fine filtering membrane of mullite. At their proposed face velocity of $5.5 \mathrm{feet} / \mathrm{minute}$, the number of filter elements required would be 2,400 . These would be packaged into two filter housings approximately 21 feet $\times 14$ feet $\times 14$ feet high.

Barrier filters are inherently efficient, and can achieve less than $5 \mathrm{ppm}$ of particulate emissions (approximately equivalent to $0.0025 \mathrm{grs} / \mathrm{scf}$ ). ${ }^{3}$ All three vendors are projecting emissions of less than $5 \mathrm{ppm}$ with efficiencies of $99.7 \%$ or better. The three vendors also projected pressure drops ranging from 15 to 20 inches of water. A maximum of 7 inches of water is available. Superior Graphite wants some margin, and a fan upgrade is included in the design.

All three filter element materials have been utilized by their respective vendors in barrier filter applications. High-density silicon carbide is the most common type of filter element and has been tested extensively in the DOE hot gas cleanup program for coal gasification and pressurized fluidized-bed combustion (PFBC). These applications are at a higher temperature (1200 to $1500^{\circ} \mathrm{F}$ ) and pressure (10 to $25 \mathrm{~atm}$ ) than the Superior Graphite applications. For these applications, the silicon carbide filter elements displayed better strength retention and creep stability than other candidates did. $^{7}$

Ceramic fiber candle filters have been developed to provide a material that is more flexible than monolithic ceramics and does not fail in a brittle manner but is not as strong. Low-density aluminosilicate fiber elements have been utilized widely in the United States and Europe. This element is similar to the Cerel elements utilized at the Coventry Homefire Works.

Sintered stainless steel elements have also been utilized in several applications. Failures were reported in a reducing gasification atmosphere due to sulfur attack. However, this should not occur in an oxidizing atmosphere. Due to the high $\mathrm{SO}_{3}$ concentration $(80 \mathrm{ppm})$ in the Superior Graphite flue gas and a relatively high dew point, acid corrosion of the filter elements could be a concern.

Face velocity (acfm flue gas $/ \mathrm{t}^{2}$ filter area) is an important parameter since it determines the number of candles needed, the pressure drop, and the size/cost of the filter. It is difficult, a priori, to predict face velocity, and testing is usually performed. In this conceptual design study, the vendors used their judgment and experience to select a face velocity.

Vendor 1's design results in a face velocity of $8 \mathrm{feet} /$ minute, which is similar to that recommended for the Coventry Homefire Works filter - 7.2 feet/minute. ${ }^{11}$ This results in 1,632 filter elements, which can be packaged into a filter that would fit into the available bay. Vendor 2's design results in a face velocity of 6 feet/minute, requiring 2,088 filter elements, which are packaged into two filters and would require expanding the bay to 70 feet high in order to remove the filter elements. Vendor 3's design results in a face velocity of 5.5 feet/minute, requiring 2,400 filter elements, which are packaged into two filter vessels and would require expanding the bay outward.

Vendor 1's proposed cost is less than that of Vendor 3, primarily because of fewer candles. On a per candle basis, the costs of both are approximately the same. Vendor 2's cost is higher both absolutely and on a per candle basis. 
Predicted removal efficiency and pressure drop proposed by all three vendors are similar. Vendors 1 and 3 proposed ceramic filter elements that are more appropriate for the high $\mathrm{SO}_{3}$ conditions than the sintered stainless steel elements. Because of this and the higher costs, Vendor 2 was eliminated from further consideration. The selection of either Vendor 1 or Vendor 3 is considered premature without having the results of a pilot test program to identify the performance characteristics of their filter elements in the Superior Graphite application. Therefore, conceptual designs and capital cost estimates have been generated for both options.

\subsection{OTHER SYSTEMS AND EQUIPMENT}

\subsubsection{ID Fan Functional Specification}

The following functional specification is based on total flow through the system. If the specification applies to multiple fans, the flows should be assigned proportionately to each fan.

Table 4-4

Fan Functional Specification

\begin{tabular}{|c|c|}
\hline Operating Temperature & $\begin{array}{l}\text { Design temperature: } 350^{\circ} \mathrm{C}\left(662^{\circ} \mathrm{F}\right) \\
\text { Normal operating: } 250-325^{\circ} \mathrm{C}\left(480-620^{\circ} \mathrm{F}\right) \\
\text { Excursions to } 375^{\circ} \mathrm{C}\left(707^{\circ} \mathrm{F}\right)\end{array}$ \\
\hline Site Altitude & 568 feet \\
\hline Static Pressure & 36 inches w.g. at maximum flow \\
\hline Total Gas Flow & $\begin{array}{l}84,000 \text { tb/hour or } 38,000 \mathrm{acfm} \text { with maximum } \\
\text { furnace output }\end{array}$ \\
\hline \multicolumn{2}{|l|}{ Inlet Gas Composition and Properties } \\
\hline Gas Density & $0.035 \mathrm{lb} / \mathrm{ft}^{3}$ \\
\hline Molecular Weight & 28.99 \\
\hline Particulates & $\begin{array}{l}\text { Particulate-free when filter is on-line } \\
\begin{array}{r}\text { When gas is bypassed through multiclone: } \\
8 \text { micron particles containing }>75 \% \mathrm{C} \\
\text { Loading: } 0.2 \text { grains/act }\end{array}\end{array}$ \\
\hline \multicolumn{2}{|l|}{ Gas Composition, Volume Percent } \\
\hline $\begin{array}{ll} & \text { Nitrogen } \\
\end{array}$ & 79.1 \\
\hline Oxygen & 18.2 \\
\hline $\mathrm{CO}_{2}$ & 0.8 \\
\hline $\mathrm{SO}_{2}$ & 0.7 \\
\hline $\mathrm{SO}_{3}$ & 0.008 (80 ppmv) \\
\hline $\mathrm{H}_{2} \mathrm{O}$ & 1.2 \\
\hline Operating Voltage & 480 Vac, 3 phase \\
\hline ID Fan I\&C & Supplied by vendor \\
\hline Motor Control Center & Supplied by others \\
\hline Material Considerations & $160^{\circ} \mathrm{C}$ sulfuric acid dewpoint \\
\hline
\end{tabular}


In response to the functional specification, Howden Fan Company provided a budget estimate to retrofit the existing housings with new rotors, resulting in a performance upgrade.

\subsubsection{Damper and Ducting Arrangement}

As required, the filter will be connected with 36 -inch insulated steel duct. This will include:

- Duct to multiclone inlet

- Duct to filter

- Duct from filter

- Duct to ID fan

- Duct from ID fan to quench

The isolation dampers are of the wafer-man-safe type with a design pressure of 36.0 inches w.g. Each 36-inch damper has an electric actuator and its own seal air fan. Zero leakage is specified with the seal air fan running. Composite expansion joints are also provided, with operating temperature of $707^{\circ} \mathrm{F}$ at 36.0 inches w.g.

\subsubsection{Nitrogen Inerting System}

The nitrogen supply for inerting the filter is located on-site. A nitrogen compressor rated at $100 \mathrm{scfm}$ is used to fill a storage tank at $150 \mathrm{psig}$. Piping to the filter is through 4-inch schedule 40 steel pipe. A fast-opening ball valve is controlled to dump the tank contents into the filter if an unsafe condition is present.

\subsection{CONCEPTUAL DESIGNS}

\subsubsection{Vendor 1 Design}

The conceptual design utilizing the barrier filter design supplied by Vendor 1 is characterized by its more compact size. This results in the filter housing being able to be installed in the bay of the scrubber building without major structural expansion of the building. Figure 4-3 is the plot plan for this design.

\section{Particulate Filter Description}

Figure 4-4 is an isometric drawing of the particulate filter housing. The overall dimensions of the housing are 7.6 meters ( 25 feet) long by 5.5 meters ( 18 feet) wide by 4.6 meters ( 15 feet) high. The filter is located in the vacant bay of the scrubber building on the ground floor. The filter housing from Vendor 1 is relatively compact, and can fit within the scrubber building bay. The filter housing is fabricated of mild steel, insulated with a 1-inch ceramic blanket. The dirty gas inlet to the filter enters through the south side of the scrubber bay and is joined with a transition joint to the filter housing. 


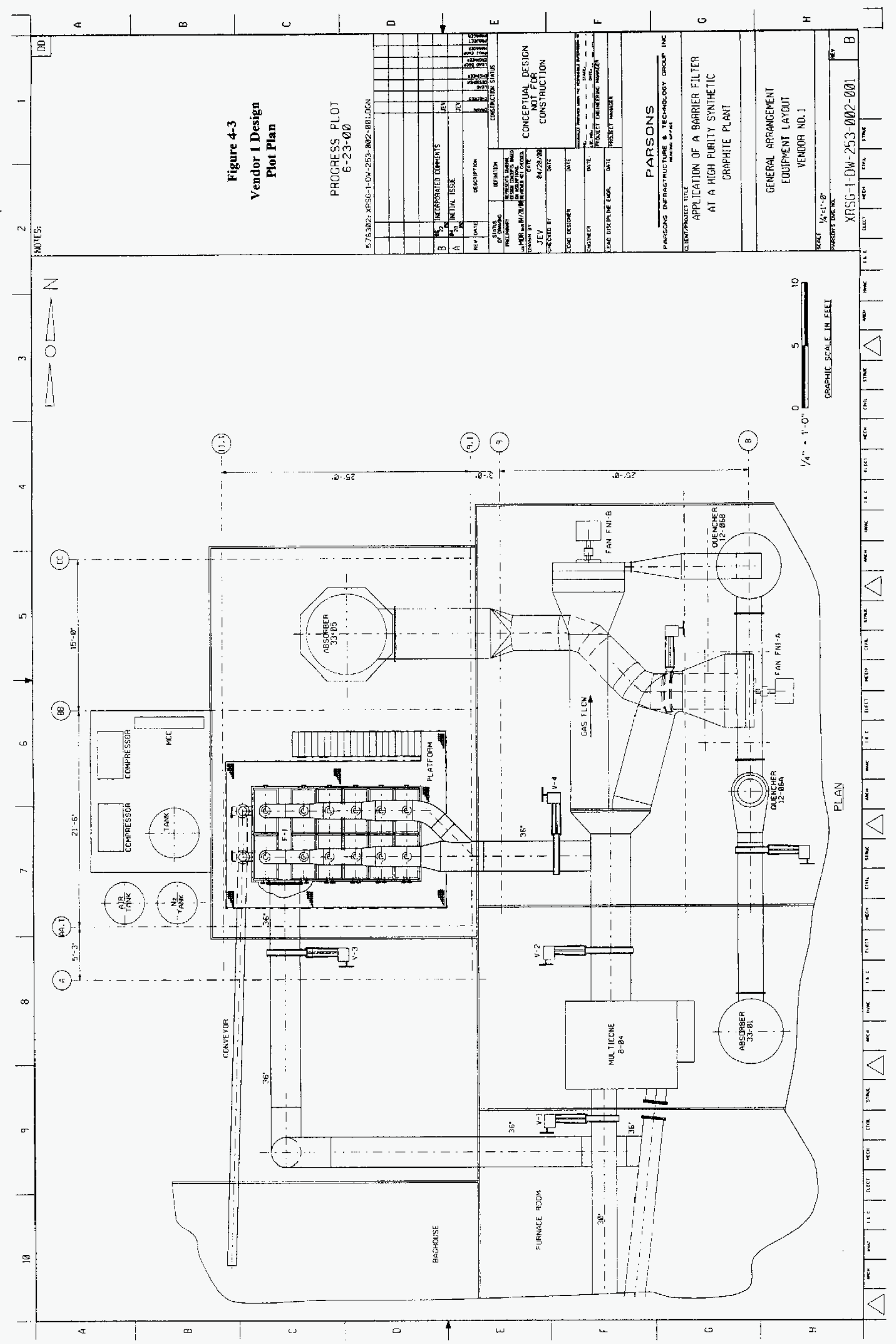


Figure 4-4

Vendor 1 Design

Filter Vessel Isometric

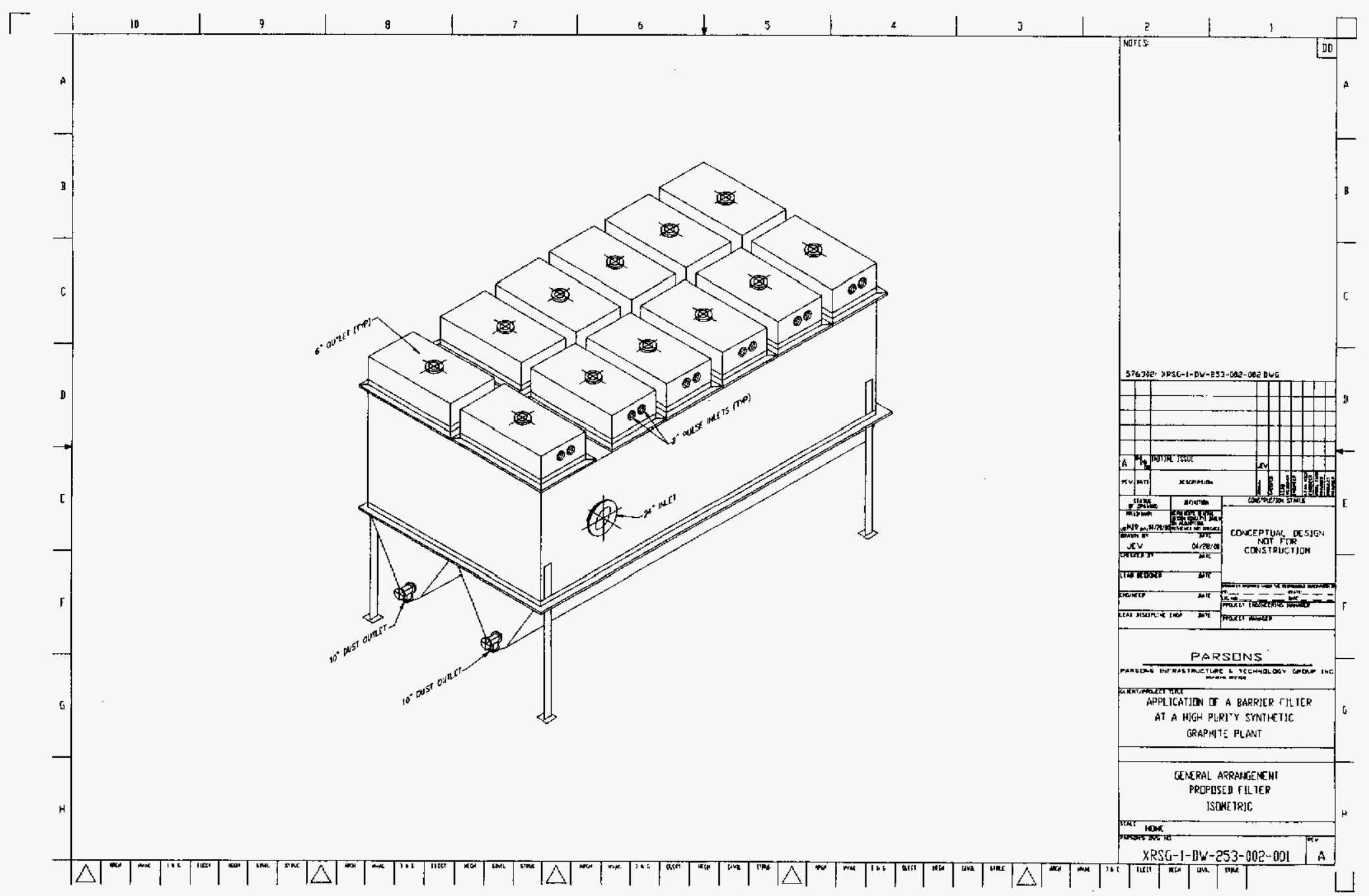


The filter housing is comprised of 12 filter modules, two columns of six rows, each containing a tube sheet 36 inches by 66 inches. Fibrosic filter candles are hung from each of the tube sheets, providing 1,632 total candles, 136 candles per module. Gas enters the outer circumference of the candles at a face velocity of 8 feet per minute, and exits above the tube sheet. The clean gas from each module exits the filter housing through a 6-inch flange, and is then manifolded across the top of the housing with a 24-inch duct. The gas leaves the scrubber building through the east wall of the bay to the ID fan suction duct.

The particulate from the dirty gas is trapped by the Fibrosic candles and is periodically removed by reverse pulsing. At a preset pressure drop or approximately once per hour, 12 liters of air per candle is blown back. The particulate falls into the hopper bottom of the filter housing and is transported by screw conveyor to the west end of the housing, directed south through the bay wall. From there, the dust is conveyed to beneath the baghouse building, and unloaded into a bin for disposal. The pulse system supplied by the filter vendor consists of a 50-cubic-foot tank for air storage at $100 \mathrm{psig}$. A blowback valve for each filter module is controlled by either a timer or by a differential pressure monitor/controller. Air for the blowback system is supplied from an onsite compressor having a capacity of $400 \mathrm{scfm}$.

\section{Equipment Relocation and Structural Changes}

The following changes from the existing plant structure and equipment configuration will be incurred with the installation of the Vendor 1 filter system:

- Cut the 30-inch and 24-inch manifold ducts, adjust plenums, install cross duct.

- Run 36-inch duct out west wall of furnace building adjacent to baghouse platform, then down and north into scrubber south wall. 36-inch penetration.

- Cut west wall of scrubber building sized to accommodate full width and height of filter vessel.

- Construct extended shed roof enclosure extending from scrubber building girder BB south 15 feet, west 12 feet, and 30 feet high.

- Remove and relocate rotary atomizer pump, rotary atomizer recycle tank, associated feed/drain piping, and other equipment from bay area to shed roof enclosure.

- Run pneumatic conveyor from dust collector of filter through south wall across open area to collection bin below baghouse. Requires 24-inch south wall penetration.

- Run 36-inch duct from top of filter vessel to elevation 17 feet and through east wall of scrubber building. Cut existing duct above wye and insert tee duct. Connect 36 -inch through transition to tee stub.

- Cut existing inlet and outlet lines to multiclone to install damper valves.

\section{Other Process Equipment}

- Fans will be upgraded per Howden Fan quotation and recommendations. This will include new fan rotors, while retaining existing motors and motor control centers. 
- Nitrogen source will be excess capacity of on-site nitrogen plant. Nitrogen compressor to be located in new shed extension on west side. 3,000-cubic-foot nitrogen storage tank to be outside.

- Air compressor for blowback to be located in new shed extension on west side. Air storage tank to be outside.

- Additional electrical requirements $(480 / 60 / 3 \mathrm{ph})$. Load center to be located within bay.

Raceways and wiring as required.

- Nitrogen compressor

$20 \mathrm{hp}(15 \mathrm{~kW})$

- Air compressor $25 \mathrm{hp}(20 \mathrm{~kW})$

- Wafer damper valves $1 \mathrm{hp}(1 \mathrm{~kW})$

- Filter pulse controls $2 \mathrm{~kW}$

- Nitrogen purge $1 \mathrm{~kW}$

- Misc. I\&C, house $20 \mathrm{~kW}$

\subsubsection{Vendor 3 Design}

The conceptual design utilizing the barrier filter design supplied by Vendor 3 is characterized by its required large footprint, due to having two filter vessels, each 26 feet by 19 feet in size. This results in there being no space available in the bay of the scrubber building, major structural expansion of the building, and disruption of the surrounding area. Figure 4-5 is the plot plan for this design.

\section{Particulate Filter Description}

Figure 4-6 is an isometric drawing of the particulate filter housing. The overall dimensions of the housing are 7.9 meters ( 26 feet) long by 5.8 meters ( 19 feet) wide by about 5 meters ( 16 feet) high. The two filter vessels are located in the vacant bay of the scrubber building, but due to their size, the south and west walls of the bay will be removed up to elevation 30 feet. Equipment, piping, and wiring will be removed and relocated. Shed roof shelter extensions will be constructed out approximately 15 feet west and 25 feet south to accommodate the filter housings. As the southward expansion will interfere with access to the pumps and tanks beneath the existing dust collector (baghouse), the filter vessels will be elevated 8 feet above ground level.

The filter housing is fabricated of mild steel, insulated with a 1-inch ceramic blanket. The dirty gas inlet to the filter enters through the south side of the scrubber bay and is joined with a transition joint to the filter housing. 


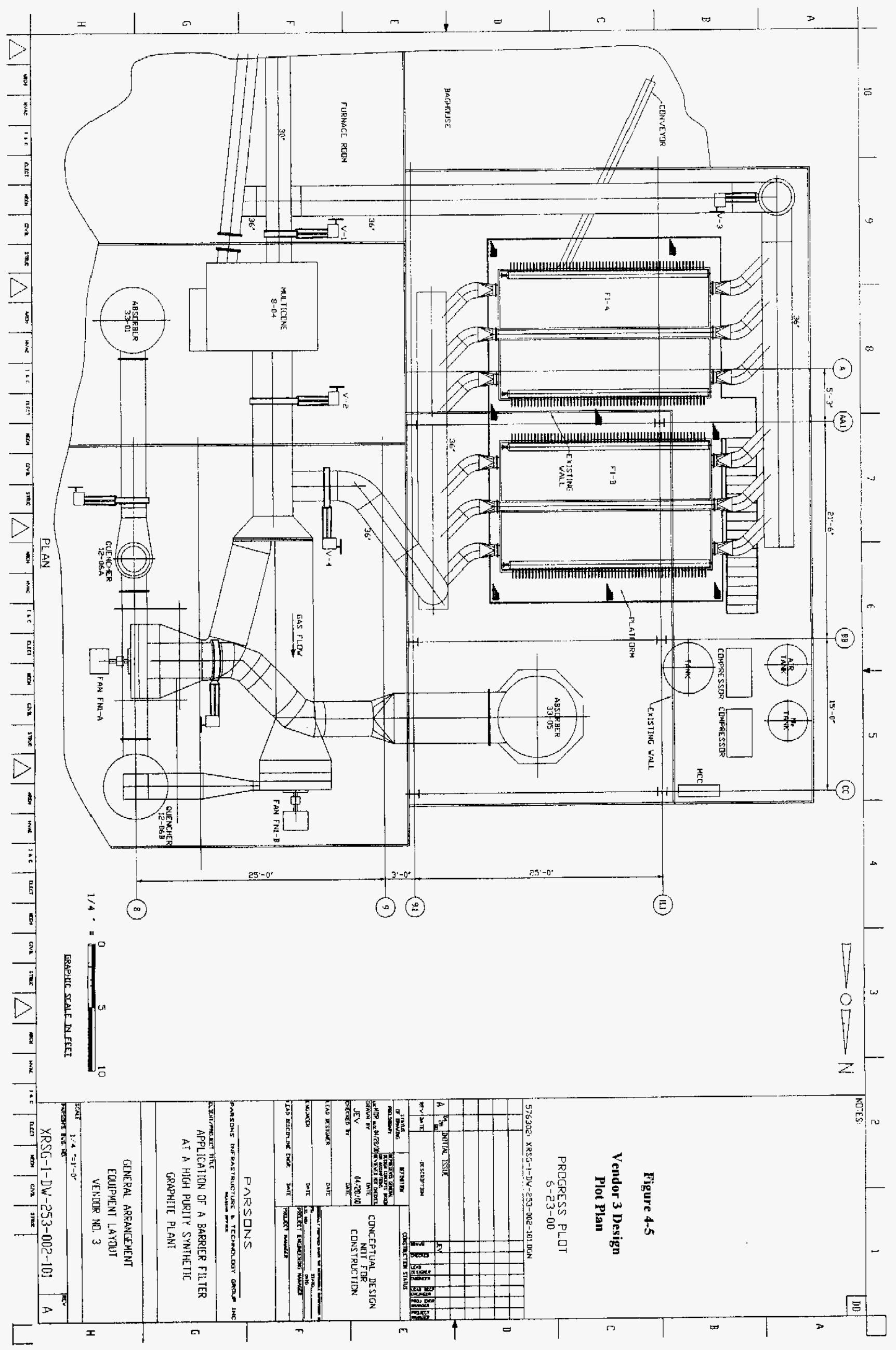




\section{Figure 4-6}

\section{Vendor 3 Design}

Filter Vessel Isometric

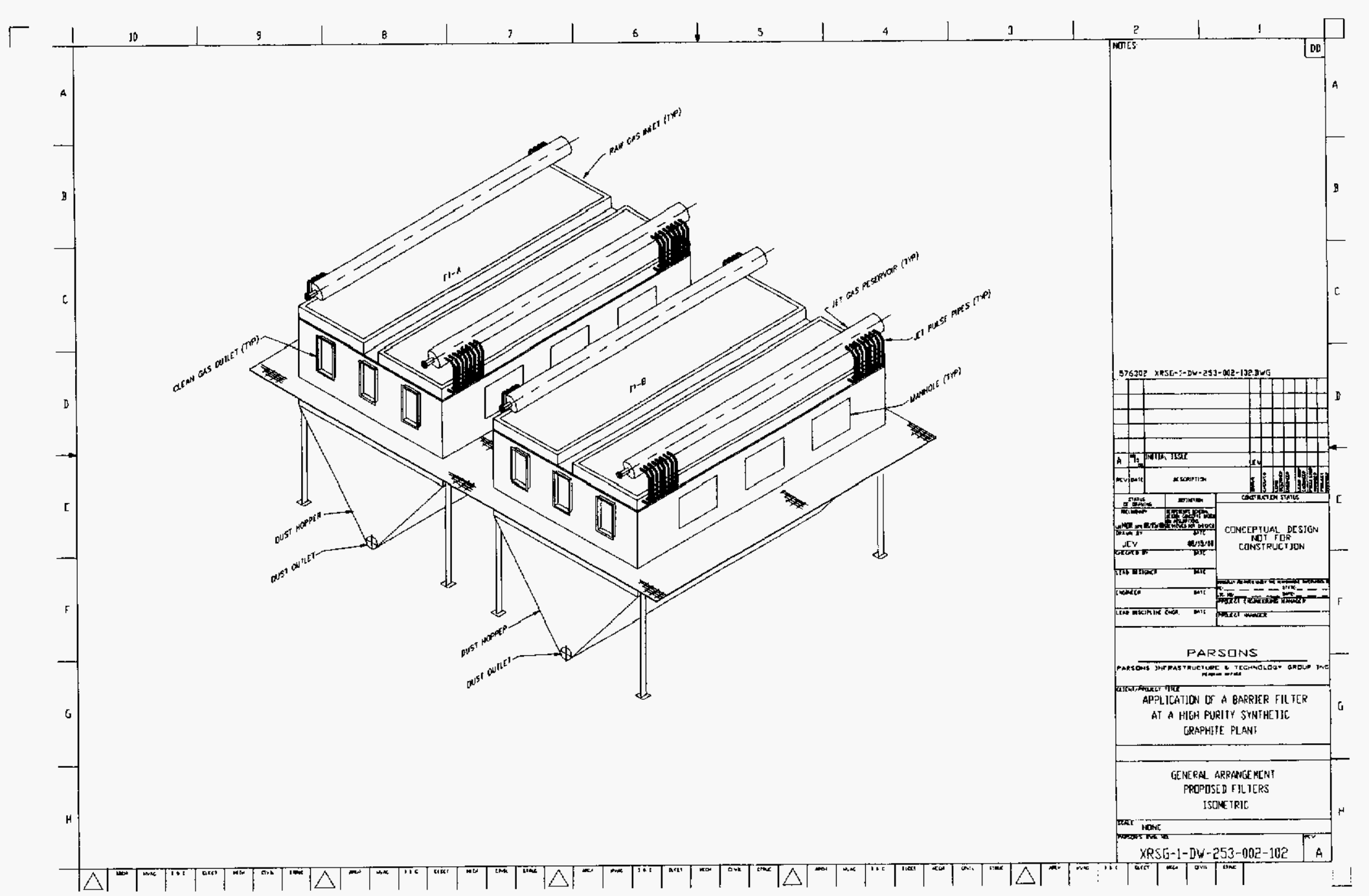


Each filter housing contains 1,200 filter candles. Silicon carbide filter candles are hung from tube sheets, providing 2,400 total candles. Gas enters the outer circumference of the candles at a face velocity of 5 feet per minute, and exits above the tube sheet. The dirty gas leaves the 36 -inch duct and enters the filter housings through 12 -inch by 6 -inch flanged ports (three in each housing). Clean gas from each vessel exits the filter housing through similar 12 -inch by 6 -inch flanged ports at the opposite end, and is manifolded with another 36-inch duct. The gas leaves the scrubber building through the east wall of the bay to the $\mathrm{ID}$ fan suction duct.

The particulate from the dirty gas is trapped by the $\mathrm{SiC}$ candles and is periodically removed by reverse pulsing. At a preset pressure drop or approximately once per hour, 12 liters of air per candle is blown back. The particulate falls into the hopper bottom of the filter housing and is transported by screw conveyor to the west end of the housing, directed south through the bay wall. From there, the dust is conveyed to beneath the baghouse building, and unloaded into a bin for disposal. The pulse system supplied by the filter vendor consists of a 50-cubic-foot tank for air storage at $100 \mathrm{psig}$. A blowback valve for each filter module is controlled by either a timer or a differential pressure monitor/controller. Air for the blowback system is supplied from an on-site compressor having a capacity of $400 \mathrm{scfm}$.

\section{Equipment Relocation and Structural Changes}

The following changes from the existing plant structure and equipment configuration will be incurred with the installation of the Vendor 3 filter system:

- Remove west and south walls of scrubber building up to elevation 30 feet.

- Construct extended shed roof enclosures on west and south sides of scrubber building. West side enclosure to be extended 15 feet. South side enclosure to be extended to meet baghouse, effectively integrating baghouse, scrubber building, and furnace building up to elevation 30 feet.

- Remove and relocate equipment and structures interfering with scrubber building extension.

- Remove and relocate rotary atomizer pump, rotary atomizer recycle tank, associated feed/drain piping, and other equipment from bay area to north end of west side shed roof enclosure.

- Provide steel structure for filter vessels, resulting in 8-foot-high access clearance beneath filter vessels.

- Cut the 30-inch and 24-inch manifold ducts, adjust plenums, install cross duct.

- Run 36-inch duct out west wall of furnace building adjacent to baghouse platform, then down and north into filter vessel area.

- Run pneumatic conveyor from dust collector of filter across south of scrubber building to collection bin below baghouse.

- Run 36-inch duct from top of filter vessel through east wall of scrubber building. Cut existing duct above wye and insert tee duct. Connect 36-inch duct through transition to tee stub. 
- Cut existing inlet and outlet lines to multiclone to install damper valves.

\section{Other Process Equipment}

- Fans will be upgraded per Howden Fan quotation and recommendations. This will include new fan rotors, while retaining existing motors and motor control centers.

- Nitrogen source will be excess capacity of on-site nitrogen plant. Nitrogen compressor to be located in new shed extension on west side. 6,000-cubic-foot nitrogen storage tank to be outside.

- Air compressor for blowback to be located in new shed extension on west side. Air storage tank to be outside.

- Additional electrical requirements ( $480 / 60 / 3 \mathrm{ph})$. Load center to be located within bay. Raceways and wiring as required.

- Nitrogen compressor

- Air compressor

- Wafer damper valves

- Filter pulse controls

- Nitrogen purge

- Misc. I\&C, house
$20 \mathrm{hp} \mathrm{(15 \textrm {kW } )}$

$25 \mathrm{hp}(20 \mathrm{~kW})$

$1 \mathrm{hp}(1 \mathrm{~kW})$

$2 \mathrm{~kW}$

$1 \mathrm{~kW}$

$20 \mathrm{~kW}$ 


\subsection{COST ESTIMATE}

The estimate basis for the U.S. DOE Superior Graphite Plant Filter Retrofit is as follows.

\section{Capital Costs}

- This is a conceptual estimate for the retrofit of a furnace off-gas stream with a barrier filter.

- The accuracy of this estimate is $\pm 30 \%$.

- All costs in the estimate are expressed in year 2000 dollars. Escalation is not included.

- The quantities in the estimate were supplied by others, and costs are based on vendor budgetary quotes, Parsons E \& $\mathrm{C}$ database, and other current information

- Allowance for any contaminated soil disposal is not included.

- All environmental permitting and project licensing to be obtained by owner.

- All risk insurance included in contractor's indirect costs.

- Building permits not included.

- Bonds, including performance, payment, and retainage, are excluded.

- Project-specific errors and omissions insurance policy not included.

- Craft hourly rate includes base rate, union fringe benefits, payroll insurances, taxes, indirect costs, and overhead/profit.

- Estimate includes a $25 \%$ contingency.

- Owner's costs are not included.

\section{Operating \& Maintenance}

- Estimated life of the candles for Vendor 1 under normal conditions is 3 years. The cost to replace one complete set of candles in year 2000 dollars is $\$ 375,000$. Gasket replacement any time a candle is removed costs $\$ 33 /$ set, or $\$ 53,850$ for complete candle replacement.

- Estimated life of the candles for Vendor 3 under normal conditions is greater than 15,000 hours. The cost to replace one complete set of candles in year 2000 dollars is $\$ 550,000$.

- Rotating equipment would require normal scheduled preventative maintenance and visual inspections.

\section{Cost Estimate for Vendor 1 Design}

Table 5-1 is the detailed estimate, and Table 5-2 is the equipment list.

\section{Cost Estimate for Vendor 3 Design}

Table 5-3 is the detailed estimate, and Table 5-4 is the equipment list. 
Table 5-1

Superior Graphite Plant Filter Retrofit CRADA

Detailed Estimate for Vendor 1 Design

CLIENT: U.S. DEPT. OF ENERGY

PROJECT: SUPERIOR GRAPHITE PLANT FILTER REIROFIT DESCRIPTION: BARRIER FILTER INSTALLATION

W. O. NO: $737324-00100$

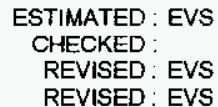

DATE : 26-Apr-O0

DATE

DATE : 29-Jun-00

DATE : 14-Aug-00

FHLE: C:MCRAPHIEFILTERRZCLIENT XLS

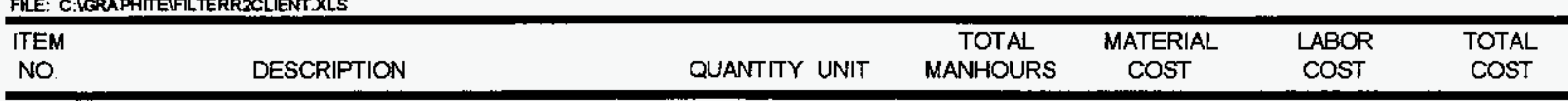

VENDOR 1 SCENARIO

EQUIPMENT

BARRIER FILTER MODULE (F1) w/ INSTRUMENTS

1668 Candle at 8FPM. $14.5^{\prime} \mathrm{H} \times 20^{\prime} \mathrm{L} \times 6^{\circ} \mathrm{W}$

BARRIER FILTER PLATFORM

Grating, Handrail, Stairs

PNEUMATIC CONVEYOR

From Fitter to Baghouse, 44

ID FAN UPGRADE (FN1-A, FN1-B) INCL, HOUSING $M \quad 2$ EA $19,000 \mathrm{CFM}, 36 "$ SP. Retrofit wheel, 66.5" dia, 131 BHP @ $1750 \mathrm{rm}$

COMPRESSOR (N2-1), $100 \mathrm{CFM}, 150 \mathrm{PSi}$ w/ $3000 \mathrm{SCF}$

1 EA

Nitrogen Supply

COMPRESSOR (B8-1), 400 CFM, $100 \mathrm{PSI}$ w/ 1000 SCF

Compressed Air Blowback System

COMPRESSOR FOUNDATIONS

INSTALL OVERHEAD DOOR (INCLUDES CUTTING O

1 EA

2 EA

SUBTOTAL

1 EA

1 EA
1 EA
1 EA
2 EA
Tm
1 EA
1 EA
2 EA
1 EA

\begin{tabular}{rrrr}
380 & 907,100 & 30,400 & 937,500 \\
119 & 6,410 & 9,520 & 15,930 \\
112 & 8,800 & 8,960 & 17,760 \\
1,056 & 76,000 & 84,480 & 160,480 \\
35 & 17,330 & 2,800 & 20,130 \\
66 & 49,650 & 5,280 & 54,930 \\
81 & 880 & 6,480 & 7,360 \\
128 & 2,000 & 10,240 & 12,240 \\
& & & \\
\hline 1,977 & $\mathbf{1 , 0 6 8 , 1 7 0}$ & $\mathbf{1 6 8 , 1 6 0}$ & $\mathbf{1 , 2 2 6 , 3 3 0}$
\end{tabular}

DUCTWORK \& DAMPERS

DAMPERS \& EXPANSION JOINTS

PAINT

DAMPERS (V-1), 30' DIA, 0\% LEAK, SEAL AIR, M.O.

DAMPERS (V-2,3,4), 36" DIA., 0\% LEAK, SEAL AIR, M.

EXP. JOINTS, $36^{\prime \prime}$ DIA.

BUIDING DUCT PENETRATIONS

DUCT PLATE \& STIFFENERS

FILTER MANIFOLD

DUCT, 3/16" X 36" DIA

ELBOW, 3/16" $\times 36^{\prime \prime}$ DIA

TEE, 3/16" $\times 36^{\prime \prime}$ DIA.

CROSS, 316" $\times 30^{\prime \prime}$ DIA

DUCT SUPPORT STEEL (MISC HANGERS)

INSULATION, CAL SIL WIJKT, 3' THICK

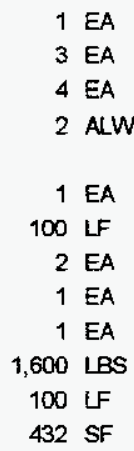

SUBTOTAL

EA

ALW

EA

LF

EA

EA

EA

100 UF

432 SF

$\begin{array}{r}53 \\ 177 \\ 106 \\ 141 \\ 44 \\ 211 \\ 38 \\ 25 \\ 26 \\ 53 \\ 440 \\ 10 \\ \hline\end{array}$

14,810

49,550

11,250

1,000

21,000

12,500

2,250

1,500

1,560

1,920

9,170

70

126,580

4,240

14,160

8,480

11,280

3,520

16,880

3,040

2,000

2,080

4,240

35,200

800

105,920

232,500
19,050

63,710

19,730

12,280

24,520

29,380

5,200

3,500

3,640

6,160

44,370

870

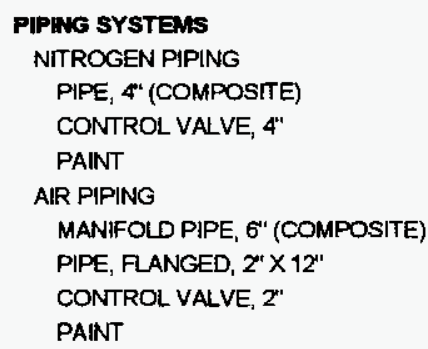

SUBTOTAL

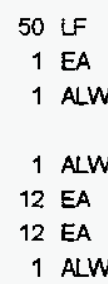

630

3,500

30

910

200

4,200

30 
Table 5-1 (Cont'd)

\section{Superior Graphite Plant Filter Retrofit CRADA Detailed Estimate for Vendor 1 Design}

\begin{tabular}{|c|c|c|c|c|c|}
\hline \multicolumn{6}{|c|}{ ELECTRICAL (ASSUMES EQUPMENT TO BE POWERED IS WITHIN 100' OF SOURCE) } \\
\hline SWITCHGEAR LINE-UP & 1 EA & 70 & 200,000 & 5,600 & 205,600 \\
\hline MOTOR CONTROL CENTER & 1 EA & 18 & 8,000 & 1,440 & 9,440 \\
\hline \multicolumn{6}{|c|}{ RACEWAY \& WIRING (POWER \& CONTROL) FOR THE FOLLOWING: } \\
\hline FILTER MODULE (DISTRIBUTION / PLC POWER) & 1 ALW & 23 & 230 & 1,840 & 2,070 \\
\hline SCREW CONVEYORS & $1 \mathrm{ALW}$ & 85 & 900 & 6,800 & 7,700 \\
\hline DAMPERS, SEAL AIR FANS, \& CONTROL VALVES & 1 ALW & 377 & 3,970 & 30,160 & 34,130 \\
\hline NITROGEN COMPRESSOR & $1 \mathrm{ALW}$ & 54 & 760 & 4,320 & 5,080 \\
\hline BLOWBACK COMPRESSOR & $1 \mathrm{ALW}$ & 83 & 1,830 & 6,640 & 8,470 \\
\hline SUBTOTAL & & 710 & 215,690 & 56,800 & 272,490 \\
\hline \multicolumn{6}{|l|}{ INSTRUMENTATION (CONTROL \& INDICATION) } \\
\hline PROGRAMMABLE LOGIC CONTROLLER & $1 \mathrm{LT}$ & 26 & 12,000 & 2,080 & 14,080 \\
\hline CONDUIT, 1 1/2" RGS (COMPOSITE) & $500 \mathrm{LF}$ & 110 & 1,090 & 8,800 & 9,890 \\
\hline CABLE, 8 PR \#18 TWSD & $1,000 \mathrm{LF}$ & 20 & 610 & 1,600 & 2,210 \\
\hline TERMINATIONS & 64 EA & 14 & 40 & 1,120 & 1,160 \\
\hline SUBTOTAL & & 170 & 13,740 & 13,600 & 27,340 \\
\hline \multicolumn{6}{|l|}{ RELOCATIONS \& MISCEШANEOUS } \\
\hline RELOCATE ATOMIZER RECYCLE TANK \& PIPING & 1 ALW & 211 & & 16,880 & 16,880 \\
\hline RELOCATE ATOMIZER RECYCLE PUMP \& PIPING & 1 ALW & 141 & & 11,280 & 11,280 \\
\hline RELOCATE MISCELLANEOUS ELECTRICAL INTERFE & $1 \mathrm{ALW}$ & 138 & & 11,040 & 11,040 \\
\hline MODIFY EXISTING MONORAIL FOR RELOCATIONS & $1 \mathrm{ALW}$ & 138 & & 11,040 & 11,040 \\
\hline ENCLOSURE FOR TANK, $12^{\prime} \times 16^{\prime} \times 30^{\circ} \mathrm{H}$ WIFOUNDA & 1 ALW & 443 & 8,250 & 35,440 & 43,690 \\
\hline HAZMAT DISPOSAL & I ALW & & 10,000 & & 10,000 \\
\hline SUBTOTAL & & 1,071 & 18,250 & 85,680 & 103,930 \\
\hline SUBTOTAL DIRECT COSTS & & 5,782 & $1,451,930$ & 462,560 & $1,914,490$ \\
\hline ENGINEERING & & & & & 287,170 \\
\hline CONTINGENCY $(25 \%)$ & & & & & 550,420 \\
\hline TOTAL DIRECT COSTS VENDOR 1 SCENARIO & & & & & $2,752,080$ \\
\hline SPARE CANDLES & & & & & 56,000 \\
\hline OTHER SPARE PARTS & & & & & 44,000 \\
\hline
\end{tabular}


Table 5-2

Superior Graphite Plant Filter Retrofit CRADA

Equipment List for Vendor 1 Design

\begin{tabular}{|c|c|c|c|}
\hline Identifier & Nomenclature & Description & Vendor/Source \\
\hline $\mathrm{F}-1$ & Barrier Filter Module & $\begin{array}{l}1668 \text { candles at } 8 \mathrm{fpm} \text {. } \\
\text { Module size } 14.5^{\prime} \mathrm{h}, 20^{\prime} \mid, 6^{\prime} \mathrm{w} \\
\text { Screw conveyor to outside unloading } \\
\text { hopper }\end{array}$ & Filter Vendor 1 \\
\hline FN-1-A, FN-1-B & ID Fan Upgrade & $\begin{array}{l}19,000 \mathrm{cfm}, 36^{\prime \prime} \mathrm{SP} \\
\text { Retrofit wheel, } 66.5^{\prime \prime} \text { dia } \\
131 \mathrm{BHP} \text { at } 1,750 \mathrm{pm}\end{array}$ & Howden Fan Company \\
\hline$V-1, V-2, V-3, V-3$ & $\begin{array}{l}\text { Man-Safe Wafer Damper and Expansion } \\
\text { Joint }\end{array}$ & $\begin{array}{l}36^{\prime \prime} \text { dia, man-safe, } 0 \% \text { leakage w/ seal } \\
\text { air, electric operator }\end{array}$ & Effox, Inc. \\
\hline N2-1 & Nitrogen Supply & $\begin{array}{l}150 \text { psig system } \\
\text { Compressor, } 100 \mathrm{cfm} \\
\text { Tank, } 3000 \mathrm{scf}\end{array}$ & Local \\
\hline BB-1 & Compressed Air Blowback System & $\begin{array}{l}100 \text { psig system } \\
\text { Compressor, } 400 \mathrm{cfm}\end{array}$ & Local \\
\hline $18 \mathrm{C}$ & Instrument and Control Upgrade & & \\
\hline Ductwork & Ductwork & $\begin{array}{l}100 \text { linear feet } \\
36 " \text { ID insulated steel duct } \\
4 \text { elbows } \\
1 \text { tee } \\
1 \text { cross } \\
\text { Match transitions }\end{array}$ & Local \\
\hline$\overline{S C-1}$ & Spare Candles & 250 & Filter Vendor 1 \\
\hline
\end{tabular}


Table 5-3

\section{Superior Graphite Plant Filter Retrofit CRADA}

Detailed Estimate for Vendor 3 Design

CLIENT: U.S. DEPT. OF ENERGY

PROJECT: SUPERIOR GRAPHITE PLANT FILTER RETROFIT

ESTIMATED : EVS

REVISED : EVS

DATE : 26-Apr-D0

DATE

W. O. NO: $737324-00100$

REVISED : EVS

DATE : 29-Jun-00

DATE : 14Aug-00

FLE: C:MSKAYHHIEYHLIEKKULLLIENIALS

\begin{tabular}{|c|c|c|c|c|c|c|}
\hline $\begin{array}{l}\text { ITEM } \\
\text { NO. }\end{array}$ & DESCRIPTION & QUANTITY UNIT & $\begin{array}{c}\text { TOTAL } \\
\text { MANHOURS }\end{array}$ & $\begin{array}{l}\text { MATERIAL } \\
\text { COST }\end{array}$ & $\begin{array}{l}\text { LABOR } \\
\text { COST }\end{array}$ & $\begin{array}{c}\text { TOTAL } \\
\text { COST }\end{array}$ \\
\hline
\end{tabular}

\section{VERDOR 3 SCENARIO}

EQUUIFUENT

BARRIER FILTER MODULE (F1-A, F1-B) w/ INSTRUME 1200 Candle at 5 FPM. $14.5 \mathrm{H} \times 20^{\circ} \mathrm{L} \times 6 \mathrm{~W}$

2 EA

759

$1,338,730$

60,720

$1,399,450$ BARRIER FILTER PLATFORM

Grating, Mandrail, Stairs

PNEUMATIC CONVEYOR

From Filter to Baghouse, 44

ID FAN UPGRADE (FN1-A, FN 1-B) INCL HOUSING MC 2 EA

19,000 CFM, 36" SP. Retrofit wheel, 66.5" dia, $131 \mathrm{BHP}$. $1750 \mathrm{rpm}$

COMPRESSOR (N2-1), 100 CFM, 150 PSI W/ 6000 SCF

Nitrogen Supply

COMPRESSOR (BB-1), 400 CFM, 100 PSI w/ 1000 SCF

Compressed Air Blowback System

COMPRESSOR FOUNDATIONS

STRUCTURAL STEEL TO ELEVATE EQUIPMENT

1 EA

1 EA

SUBTOTAL

2 EA

1 ALW

$\begin{array}{r}81 \\ 880 \\ \hline \mathbf{3 , 2 4 0}\end{array}$

238

112

1,056

$(20)$

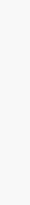

\section{DUCTWORK \& DAMPERS}

DAMPERS \& EXPANSION JOINTS

DAMPERS $(V-1), 30^{\prime}$ DIA, O\% LEAK, SEAL AIR, M.O

DAMPERS $(V-2,3,4), 36^{\circ}$ DIA., D\% LEAK, SEAL AIR, M.

EXP. JOINTS, 36" DIA

BUILDING DUCT PENETRATIONS

DUCT PLATE \& STIFFENERS

FILTER MANIFOLD

DUCT, 3/16" X 36" DIA.

ELBOW, $3 / 16^{m} \times 36^{\circ}$ DIA.

TEE, $3 / 16^{n} \times 36^{n}$ DIA.

CROSS, $3 / 16^{n} \times 30^{\prime \prime}$ DIA.

DUCT SUPPORT STEEL (MISC HANGERS)

INSULATION, CAL SIL WIJKT, 3 THICK

PAINT

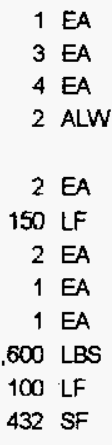

SUETOTAL

$\begin{array}{rrrr}53 & 14,810 & 4,240 & 19,050 \\ 177 & 49,550 & 14,160 & 63,710 \\ 106 & 11,250 & 8,480 & 19,730 \\ 141 & 1,000 & 11,280 & 12,280 \\ & & & \\ 88 & 42,000 & 7,040 & 49,040 \\ 317 & 18,750 & 25,360 & 44,110 \\ 38 & 2,250 & 3,040 & 5,290 \\ 25 & 1,500 & 2,000 & 3,500 \\ 26 & 1,560 & 2,080 & 3,640 \\ 53 & 1,920 & 4,240 & 6,160 \\ 440 & 9,170 & 35,200 & 44,370 \\ 10 & 70 & 800 & 870 \\ & & & \mathbf{2 7 1 , 7 5 0}\end{array}$

\section{PHFine SYSTIAS}

NITROGEN PIPING

PIPE, 4" (COMPOSITE)

CONTROL VALVE, 4"

PAINT

AIR PIPING

MANIFOLDPIPE, 6" (COMPOSITE)

PIPE, FLANGED, $2^{\prime \prime} \times 12^{*}$

CONTROL VALVE, $2^{\prime}$

PAINT

SUBTOTAL

\begin{tabular}{|c|c|c|c|c|c|}
\hline 50 & $\mathrm{LF}$ & 65 & 630 & 5,200 & 5,830 \\
\hline 1 & EA & 13 & 3,500 & 1,040 & 4,540 \\
\hline 1 & AlW & 4 & 30 & 320 & 350 \\
\hline 1 & ALW & 358 & 910 & 28,640 & 29,550 \\
\hline 24 & EA & 106 & 410 & 8,480 & 8,890 \\
\hline 24 & EA & 66 & 8,400 & 5,280 & 13,680 \\
\hline 1 & ALW & 4 & 30 & 320 & 350 \\
\hline
\end{tabular}


Table 5-3 (Cont'd)

\section{Superior Graphite Plant Filter Retrofit CRADA}

Detailed Estimate for Vendor 3 Design

\begin{tabular}{|c|c|c|c|c|c|}
\hline \multicolumn{6}{|c|}{ ELECTRICAL (ASSUMES EQUIPMENT TO BE POWERED IS WITHIN 100' OF SOURCE) } \\
\hline SWITCHGEAR LINE-UP & $1 \mathrm{EA}$ & 70 & 200,000 & 5,600 & 205,600 \\
\hline MOTOR CONTROL CENTER & $1 \mathrm{EA}$ & 18 & 8,000 & 1,440 & 9,440 \\
\hline \multicolumn{6}{|c|}{ RACEWAY \& WIRING (POWER \& CONTROL) FOR THE FOLLOWING: } \\
\hline FILTER MODULE (DISTRIBUTION / PLC POWER) & 1 AlW & 23 & 230 & 1,840 & 2,070 \\
\hline SCREW CONVEYORS & $1 \mathrm{ALW}$ & 85 & 900 & 6,800 & 7,700 \\
\hline DAMPERS, SEAL AIR FANS, \& CONTROL VALVES & 1 ALW & 377 & 3,970 & 30,160 & 34,130 \\
\hline NITROGEN COMPRESSOR & $1 \mathrm{AlW}$ & 54 & 760 & 4,320 & 5,080 \\
\hline BLOWBACK COMPRESSOR & 1 ALW & 83 & 1,830 & 6,640 & 8,470 \\
\hline SUBTOTAL & & $7 t 0$ & 215,690 & 56,800 & 272,490 \\
\hline \multicolumn{6}{|l|}{ INSTRUMENTATION (CONTROL \& INOKCATION) } \\
\hline PROGRAMMABLE LOGIC CONTROULER & $1 \mathrm{LT}$ & 44 & 16,000 & 3,520 & 19,520 \\
\hline CONDUIT, 1 t/2" RGS (COMPOSITE) & $750 \mathrm{LF}$ & 165 & 1,630 & 13,200 & 14,830 \\
\hline CABLE, 8 PR\#18 TWSD & $1,500 \mathrm{LF}$ & 30 & 920 & 2,400 & 3,320 \\
\hline TERMINATIONS & $84 \mathrm{EA}$ & 18 & 60 & 1,440 & 1,500 \\
\hline SUBTOTAL & & 257 & 18,610 & 20,560 & 39,170 \\
\hline \multicolumn{6}{|l|}{ RELOCATIONS \& MISCELLANEOUS } \\
\hline RELOCATE ATOMIZER RECYCLE TANK \& PIPING & $1 \mathrm{ALW}$ & 211 & & 16.880 & 16,880 \\
\hline RELOCATE ATOMIZER RECYCLE PUMP \& PIPING & $1 \mathrm{ALW}$ & $\uparrow 41$ & & 11,280 & 11,280 \\
\hline RELOCATE MISCELLANEOUS INTERFERENCES. & $1 \mathrm{ALW}$ & 3,520 & 168,400 & 281,600 & 450,000 \\
\hline MOOIFY EXISTING MONORAIL FOR RELOCATIONS & ALW & 138 & & 11,040 & 11,040 \\
\hline BUIDDING EXTENSION WIFOUNDATION \& UTILTIES & ALW & & 150,000 & & 150,000 \\
\hline HAZMAT DISPOSAL & $1 \mathrm{ALW}$ & & 10,000 & & 10,000 \\
\hline SUBTOTAL & & 4,010 & 328,400 & 320,800 & 649,200 \\
\hline SUBTOTAL DIRECT COSTS & & 10,307 & $\overline{2,317,650}$ & 824,560 & $3,142,210$ \\
\hline ENGNEERINO & & & & & 471,330 \\
\hline CONTINGENCY $(25 \%)$ & & & & & 903,390 \\
\hline TOTAL DARECT COSTS VENDOR 3 SCENARIO & & & & & $4,516,930$ \\
\hline SPARE CANOLES & & & & & 81,000 \\
\hline OTHER SPARE PARTS & & & & & 69,000 \\
\hline
\end{tabular}


Table 5-4

Superior Graphite Plant Filter Retrofit CRADA

Equipment List for Vendor 3 Design

\begin{tabular}{|c|c|c|c|}
\hline Identifier & Nomenclature & Description & Vendor/Source \\
\hline F-1-A, F-1-B & Bamier Filter Module & $\begin{array}{l}1200 \text { candles at } 5 \text { fpm. } \\
\text { Module size }\left\{6^{\prime} \mathrm{h}, 21^{\prime} 1,14^{\prime} \mathrm{w}\right. \\
\text { Screw conveyor to outside unloading } \\
\text { hopper }\end{array}$ & Filter Vendor 3 \\
\hline FN-1-A, FN-1-B & ID Fan Upgrade & $\begin{array}{l}19,000 \mathrm{cfm}, 36 " \mathrm{SP} \\
\text { Retrofit wheel, } 66.5^{\prime \prime} \text { dia } \\
131 \mathrm{BHP} \text { at } 1,750 \mathrm{rmm}\end{array}$ & Howden Fan Company \\
\hline$V-1, V-2, V-3, V-3$ & $\begin{array}{l}\text { Man-Safe Wafer Damper and Expansion } \\
\text { Joint }\end{array}$ & $\begin{array}{l}36 " \text { dia, man-safe, } 0 \% \text { leakage w/ seal } \\
\text { air, electric operator }\end{array}$ & Effox, Inc. \\
\hline N2-1 & Nitrogen Supply & $\begin{array}{l}150 \text { psig system } \\
\text { Compressor, } 100 \mathrm{cfm} \\
\text { Tank, } 6000 \mathrm{scf}\end{array}$ & Local \\
\hline BB-1 & Compressed Air Blowback System & $\begin{array}{l}100 \text { psig system } \\
\text { Compressor, } 400 \mathrm{cfm}\end{array}$ & Local \\
\hline I\&C & Instrument and Control Upgrade & & \\
\hline Ductwork & Ductwork & $\begin{array}{l}150 \text { linear feet } \\
36 " \text { ID insulated steel duct } \\
4 \text { elbows } \\
1 \text { tee } \\
1 \text { cross } \\
\text { Match transitions }\end{array}$ & Local \\
\hline SC-1 & Spare Candles & 360 & Filter Vendor 3 \\
\hline
\end{tabular}




\subsection{CONCLUSIONS}

- A barrier filter conceptual design was generated based on the Superior Graphite process conditions and physical layout. The barrier filter is expected to greatly reduce particulate carryover from the multiclones upstream of the scrubber. However, there is expected to be little $\mathrm{SO}_{3}$ removed by the filter without the addition of separate absorbent material. Some test work has been done on injecting absorbents into barrier filters for $\mathrm{SO}_{3}$ removal, but little if any commercial experience is available. Thus the degree to which a barrier filter upstream of the scrubber can enhance downstream stack opacity or reduce particulates in the downstream stack due to scrubber water carryover is difficult to determine (or unknown) and cannot be determined without full-scale operation.

- The Superior Graphite filter application will be unique due to its large size (designed for $40,000 \mathrm{acfm}$ ), the high percentage of carbon in the particulate $(>75 \%)$, and the relatively high oxygen content $(18 \%)$ when compared to flue gas.

- In response to an operational specification for the barrier filter, three vendors responded with an indication that they could provide filtration media. The DOE has also tested similar filters in much more severe conditions. Based on the vendor responses and DOE testing, it can be concluded that filter media are available to satisfy the Superior Graphite application.

- While guidance can be obtained from the design and operation of the Coventry Homefire Works filter, there are enough differences (coal versus coke as a carbon source, flue gas versus dilution gas, $30,000 \mathrm{acfm}$ versus $40,000 \mathrm{acfm}$ ) that it would be prudent to run pilot plant tests on the Superior Graphite dust. The use of small multi-element pilot filters in a slipstream at the Hopkinsville plant can give valuable insights into the behavior of material being filtered and provides information necessary for the finalization of the design of full-size units. An objective of the pilot plant tests would be to verify for a particular filter media the face velocity that can be used while maintaining a stable pressure drop without dust reentrainment or penetration. A second objective would be to determine the conditions necessary for preventing the combustion of solids on the filter elements in Superior Graphite's outlet gases.

- Space limitations are critical at Superior Graphite. Vendor 1's unit will fit in the existing bay. However, if pilot plant tests dictate a lower face velocity as was proposed by Vendor 3 , an expansion of the bay will be needed, with the associated higher costs. 


\subsection{REFERENCES}

${ }^{1}$ Beattie and Withers, "Applications of Low-Density Filters for Gas Cleaning at High Temperatures," Second International Symposium on Gas Cleaning at High Temperatures, University of Surrey, Guildford, UK on 27-29 September, 1993.

${ }^{2}$ Dennis, R. et al., "U.S. Department of Energy's High-Temperature and High Pressure Particulate Cleanup Program for Advanced Power Systems," Fourth International Symposium on Gas Cleaning at High Temperatures, University of Karlsruhe, Karlsruhe, Germany on 22-24 September, 1999.

3 "Assessment of Hot Gas Cleanup Systems for IGCC and PFBC Advanced Power Systems," Parsons Report No. 9607, DOE Contract No. DE-ACO1-94FE62747/ Task 18, January 1997.

${ }^{4}$ Withers \& Morson, "Ceramic Filtration of Black Smoke Emissions."

${ }^{5}$ Davidson, M., et al., "Power System Development Facility: High Temperature, High Pressure Filter Systems in a Combustion Gas," Fourth International Symposium on Gas Cleaning at High Temperatures, University of Karlsruhe, Karlsruhe, Germany on 22-24 September, 1999.

${ }^{6}$ Pontius, D. H., "Hot Gas Filtration Technical Issues," Southern Research Institute, Advanced Coal-Fired Power Systems '95 Review Meeting, June 1995.

${ }^{7}$ Spain, J. D., "Properties of Ceramic Filters," Southern Research Institute, Advanced Coal Fired Power Systems '96 Review Meeting, July 16-18, 1996.

8 "Tidd Hot Gas Cleanup Program," Final Report by Ohio Power Company, DOE Contract DEFC21-89MC26042, October 1995.

9 "Identification of Opportunities for the Use of Barrier Filters in Industrial Applications," Parsons Draft Report, DOE Contract No. DE-AC21-89MC25177/ Task 21, June 1998.

10 "Filter Out Black Smoke Emissions - The Result of a Good Practice Case Study at Cronite Precision Castings, Ltd.," 1997, ETSU Study No. GC68.

${ }^{11}$ Jones \& Rogers, "The Evaluation of Low-Density Filters in a Boiler Flue Gas Clean-Up System," Second International Symposium on Gas Cleaning at High Temperatures, University of Surrey, Guildford, UK on 27-29 September, 1993.

${ }^{12}$ Sasatsu, H., "Performance of the Advanced Ceramic Tube Filter for the Wakamatsu 71 MWe PFBC Combined Cycle Power Plant," Symposium on High-Temperature Particulate Cleanup for Advanced Coal-Based Power Systems, April 20-23, 1998.

${ }^{13}$ Personal Communication William Ellison, Ellison Consultants, December 1999. 
${ }^{14}$ Zievers, J. F. et al., "Simultaneous Hot Gas Desulfurization and Improved Filtration with Dry Scrubbing Using Waste Products," International Incineration Conference, May 12-16, 1997, Oakland, CA. 